CRYSTALLOGRAPHIC COMMUNICATIONS

ISSN 2056-9890

Received 5 March 2020

Accepted 24 March 2020

Edited by A. J. Lough, University of Toronto, Canada

Keywords: crystal structure; hydrogen bond; dihydrobenzothiazine; antibacterial activity; Hirshfeld surface.

CCDC reference: 1992626

Supporting information: this article has supporting information at journals.iucr.org/e

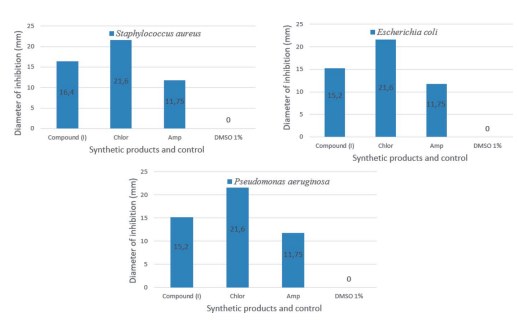

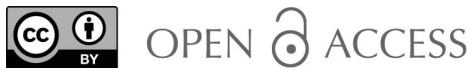

\section{Crystal structure, Hirshfeld surface analysis and interaction energy, DFT and antibacterial activity studies of ethyl 2-[(2Z)-2-(2-chlorobenzylidene)-3- oxo-3,4-dihydro-2H-1,4-benzothiazin-4-yl]acetate}

\author{
Ghizlane Sebbar, ${ }^{\mathrm{a} *}$ Ellouz Mohamed, ${ }^{\mathrm{b}}$ Tuncer Hökelek, ${ }^{\mathrm{c}}$ Joel T. Mague, \\ Nada Kheira Sebbar, ${ }^{\text {b,e }}$ El Mokhtar Essassi ${ }^{\mathrm{b}}$ and Bouchra Belkadi ${ }^{\mathrm{a}}$
}

aLaboratory of Microbiology and Molecular Biology, Faculty of Sciences, University Mohammed V, Rabat, Morocco,
${ }^{\mathbf{b}}$ Laboratoire de Chimie Organique Heterocyclique URAC 21, Pole de Competence Pharmacochimie, Faculté des
Sciences, Université Mohammed V, Rabat, Morocco, ' ${ }^{\mathbf{c}}$ Department of Physics, Hacettepe University, 06800 Beytepe,
Ankara, Turkey, ${ }^{\mathbf{d}}$ Department of Chemistry, Tulane University, New Orleans, LA 70118, USA, and ${ }^{\mathbf{E}}$ Laboratoire de
Chimie Appliquee et Environnement, Equipe de Chimie Bioorganique Appliquee, Faculte des Sciences, Université Ibn
Zohr, Agadir, Morocco. ${ }^{*}$ Correspondence e-mail: sebbar.ghizlane@um5s.net.ma

The title compound, $\mathrm{C}_{19} \mathrm{H}_{16} \mathrm{ClNO}_{3} \mathrm{~S}$, consists of chlorophenyl methylidene and dihydrobenzothiazine units linked to an acetate moiety, where the thiazine ring adopts a screw-boat conformation. In the crystal, two sets of weak C$\mathrm{H}_{\mathrm{Ph}} \cdots \mathrm{O}_{\mathrm{Dbt}}(\mathrm{Ph}=$ phenyl and $\mathrm{Dbt}=$ dihydrobenzothiazine $)$ hydrogen bonds form layers of molecules parallel to the $b c$ plane. The layers stack along the $a$ axis direction with intercalation of the ester chains. The crystal studied was a two component twin with a refined BASF of 0.34961 (5). The Hirshfeld surface analysis of the crystal structure indicates that the most important contributions to the crystal packing are from $\mathrm{H} \cdots \mathrm{H}(37.5 \%), \mathrm{H} \cdots \mathrm{C} / \mathrm{C} \cdots \mathrm{H}(24.6 \%)$ and $\mathrm{H} \cdots \mathrm{O} / \mathrm{O} \cdots \mathrm{H}(16.7 \%)$ interactions. Hydrogen-bonding and van der Waals interactions are the dominant interactions in the crystal packing. Computational chemistry indicates that in the crystal, $\mathrm{C}-\mathrm{H}_{\mathrm{Ph}} \cdots \mathrm{O}_{\mathrm{Dbt}}$ hydrogen bond energies are 38.3 and $30.3 \mathrm{~kJ} \mathrm{~mol}^{-1}$. Density functional theory (DFT) optimized structures at the B3LYP/ 6-311 G(d,p) level are compared with the experimentally determined molecular structure in the solid state. The HOMO-LUMO behaviour was elucidated to determine the energy gap. Moreover, the antibacterial activity of the title compound has been evaluated against gram-positive and gram-negative bacteria.

\section{Chemical context}

A number of pharmacological tests have revealed 1,4-benzothiazine derivatives to possess a wide spectrum of biological applications, indicating that the 1,4-benzothiazine moiety is a potentially useful template in medicinal chemistry research and therapeutic applications such as in vivo antiproliferative (Zięba et al., 2016), antibacterial (Sebbar et al., 2016b; Ellouz et al., 2019), antimicrobial (Armenise et al., 2012; Sabatini et al., 2008; Vijay \& Rahul, 2016), anti-viral (Malagu et al., 1998), anti-oxidant (Zia-ur-Rehman et al., 2009), anti-inflammatory (Trapani et al., 1985; Gowda et al., 2011), antipyretic (Warren \& Knaus, 1987) and anti-cancer (Gupta \& Gupta, 1991; Gupta et al., 1985) areas. They have also been reported as precursors for the syntheses of new compounds (Sebbar et al., 2015a; Vidal et al., 2006) possessing anti-diabetic (Tawada et al., 1990) and anti-corrosion (Ellouz et al., 2016a,b) activities, and as antiproliferative (Zięba et al., 2010) or antihelmintic (Munir- 
Table 1

Hydrogen-bond geometry $\left(\AA{ }^{\circ}\right)$.

\begin{tabular}{lllll}
\hline$D-\mathrm{H} \cdots A$ & $D-\mathrm{H}$ & $\mathrm{H} \cdots A$ & $D \cdots A$ & $D-\mathrm{H} \cdots A$ \\
\hline $\mathrm{C} 12-\mathrm{H} 12 \cdots \mathrm{O} 1^{\mathrm{vii}}$ & $0.95(3)$ & $2.56(3)$ & $3.214(2)$ & $126(2)$ \\
$\mathrm{C} 15-\mathrm{H} 15 \cdots 1^{\mathrm{ii}}$ & $0.95(2)$ & $2.40(2)$ & $3.227(2)$ & $145.8(15)$ \\
\hline
\end{tabular}

Symmetry codes: (ii) $-x+1,-y+1,-z+1$; (vii) $-x+1, y+\frac{1}{2},-z+\frac{1}{2}$.

ajasekar et al., 2011) agents. The biological activities of some 1,4-benzothiazines are similar to those of phenothiazines, featuring the same structural specificity (Hni et al., 2019a,b; Ellouz et al., 2017a, 2018, 2019; Sebbar et al., 2019a,b). In a continuation of our research activities devoted to the development of $\mathrm{N}$-substituted 1,4-benzothiazine derivatives and the evaluation of their potential pharmacological activities (Ellouz et al., 2017a; Sebbar et al., 2017a), we have synthesized a new heterocyclic system containing 1,4-benzothiazine. We report herein the synthesis and the molecular and crystal structures along with the Hirshfeld surface analysis and interaction energy calculations [using the CE-B3LYP/6$31 \mathrm{G}(\mathrm{d}, \mathrm{p})$ energy model] and the density functional theory (DFT) computational calculations carried out at the B3LYP/ 6-311 G(d,p) level compared with the experimentally determined molecular structure in the solid state. Moreover, the antibacterial activity of the title compound has been evaluated against gram-positive and gram-negative bacteria (e.g. Staphylococcus aureus, Escherichia coli and Pseudomonas aeruginosa).

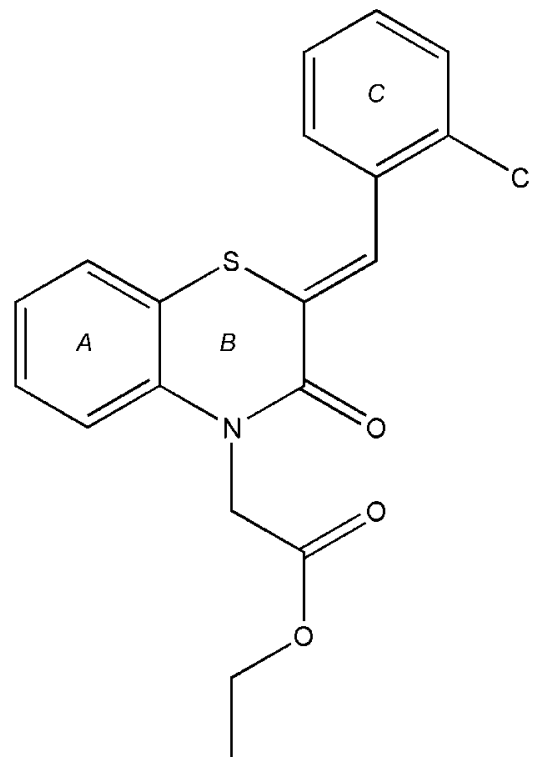

\section{Structural commentary}

The title compound, (I), consists of chlorophenyl methylidene and dihydrobenzothiazine units linked to an acetate moiety, where the thiazine ring adopts a screw-boat conformation (Fig. 1). The dihydrobenzothiazine ring is folded across the $\mathrm{N} 1 \cdots \mathrm{S} 1$ axis by $36.70(7)^{\circ}$. A puckering analysis of the thiazine, $B(\mathrm{~N} 1 / \mathrm{S} 1 / \mathrm{C} 1 / \mathrm{C} 6-\mathrm{C} 8)$, ring conformation gave the para-

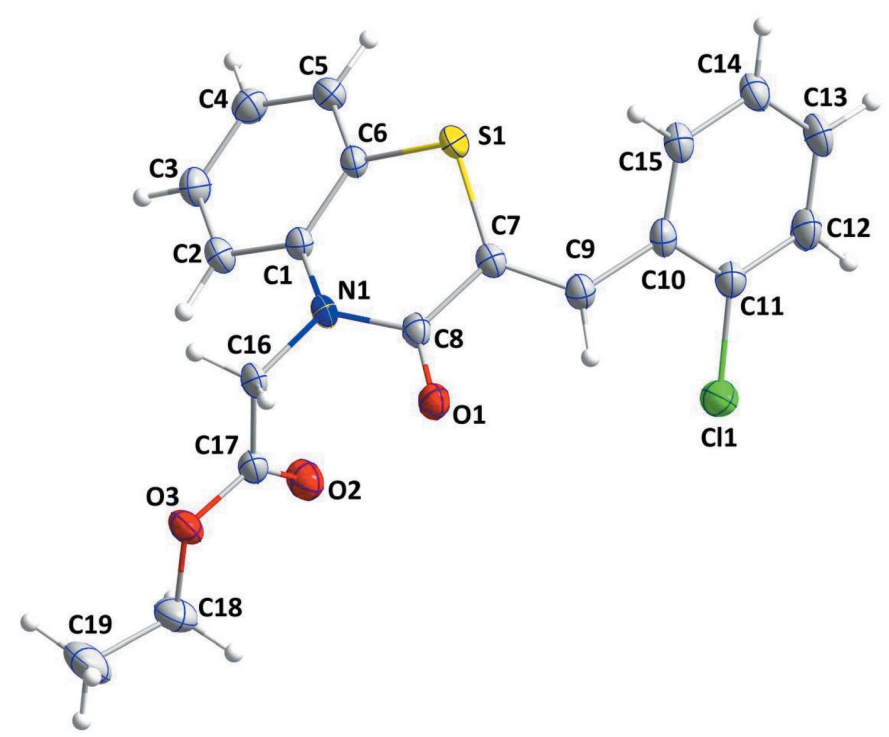

Figure 1

The asymmetric unit of the title compound with the atom-numbering scheme. Displacement ellipsoids are drawn at the $50 \%$ probability level.

meters $Q_{\mathrm{T}}=0.5525(16) \AA, \theta=109.0(2)^{\circ}$ and $\varphi=161.0(2)^{\circ}$, indicating a screw-boat conformation. The mean plane of the $\mathrm{N} 1 / \mathrm{C} 16 / \mathrm{C} 17 / \mathrm{O} 2 / \mathrm{O} 3$ group is inclined to the mean plane of the $\mathrm{S} 1 / \mathrm{C} 1-\mathrm{C} 6 / \mathrm{N} 1$ unit by $80.06(7)^{\circ}$ while the phenyl, $C$ (C10$\mathrm{C} 15)$, ring makes a dihedral angle of $84.92(6)^{\circ}$ with the latter plane. The benzene ring $A$ (C1-C6) is oriented at a dihedral angle of $84.46(2)^{\circ}$ with respect to the $C$ ring.

\section{Supramolecular features}

In the crystal, two sets of weak $\mathrm{C}-\mathrm{H}_{\mathrm{Ph}} \cdots \mathrm{O}_{\mathrm{Dbt}}(\mathrm{Ph}=$ phenyl and $\mathrm{Dbt}=$ dihydrobenzothiazine) hydrogen bonds (Table 1 ) form layers of molecules parallel to the $b c$ plane (Fig. 2). The layers stack along the $a$-axis direction with intercalation of the ester chains (Fig. 2).

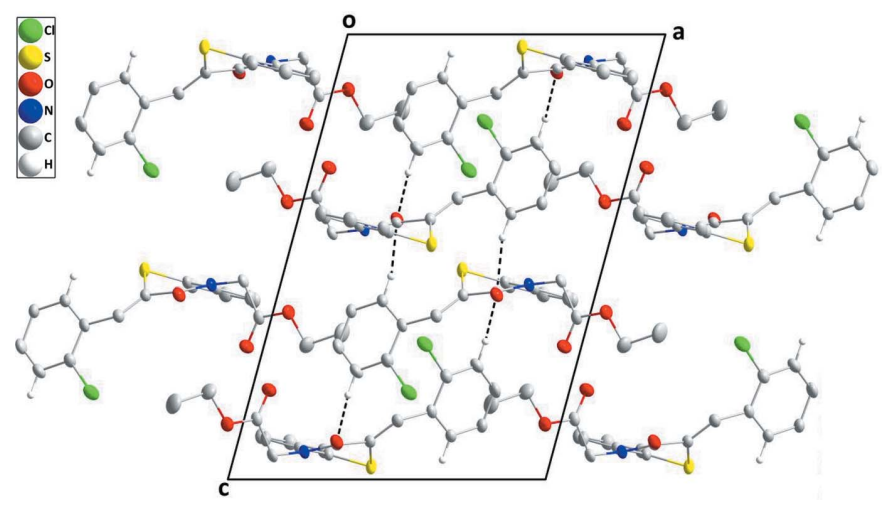

Figure 2

A partial packing diagram viewed along the $b$-axis direction. The weak $\mathrm{C}-\mathrm{H}_{\mathrm{Ph}} \cdots \mathrm{O}_{\mathrm{Dbt}}(\mathrm{Ph}=$ phenyl and $\mathrm{Dbt}=$ dihydrobenzothiazine $)$ hydrogen bonds are depicted by black dashed lines. 


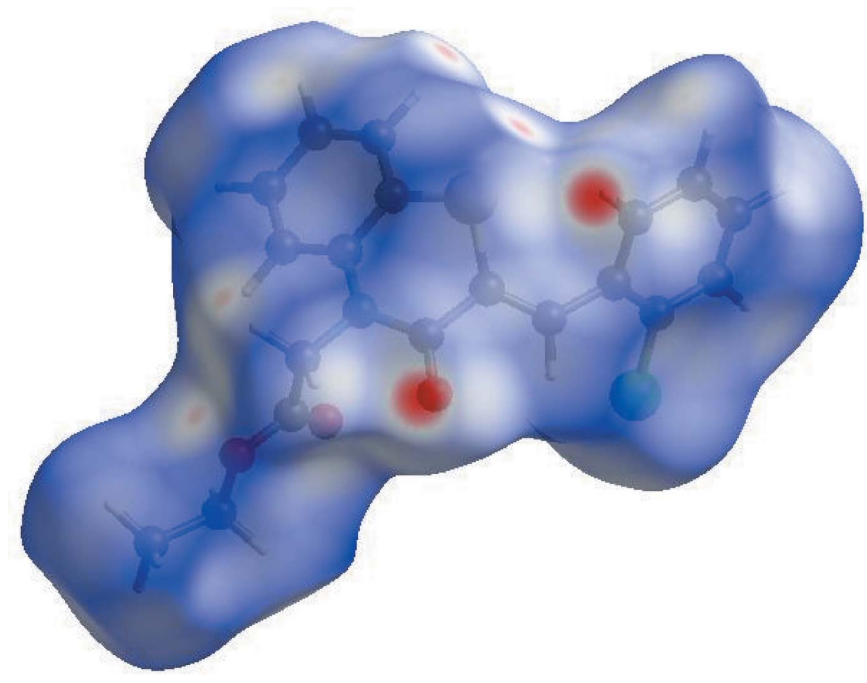

Figure 3

View of the three-dimensional Hirshfeld surface of the title compound plotted over $d_{\text {norm }}$ in the range -0.1956 to 1.3971 a.u.

\section{Hirshfeld surface analysis}

In order to visualize the intermolecular interactions in the crystal of the title compound, a Hirshfeld surface (HS) analysis (Hirshfeld, 1977; Spackman \& Jayatilaka, 2009) was carried out using Crystal Explorer 17.5 (Turner et al., 2017). In the HS plotted over $d_{\text {norm }}$ (Fig. 3), the white surface indicates contacts with distances equal to the sum of van der Waals radii, and the red and blue colours indicate distances shorter (in close contact) or longer (distant contact) than the van der Waals radii, respectively (Venkatesan et al., 2016). The brightred spots appearing near $\mathrm{O} 1$ and hydrogen atom $\mathrm{H} 15$ indicate their roles as the respective donors and/or acceptors; they also appear as blue and red regions corresponding to positive and negative potentials on the HS mapped over electrostatic potential (Spackman et al., 2008; Jayatilaka et al., 2005) as

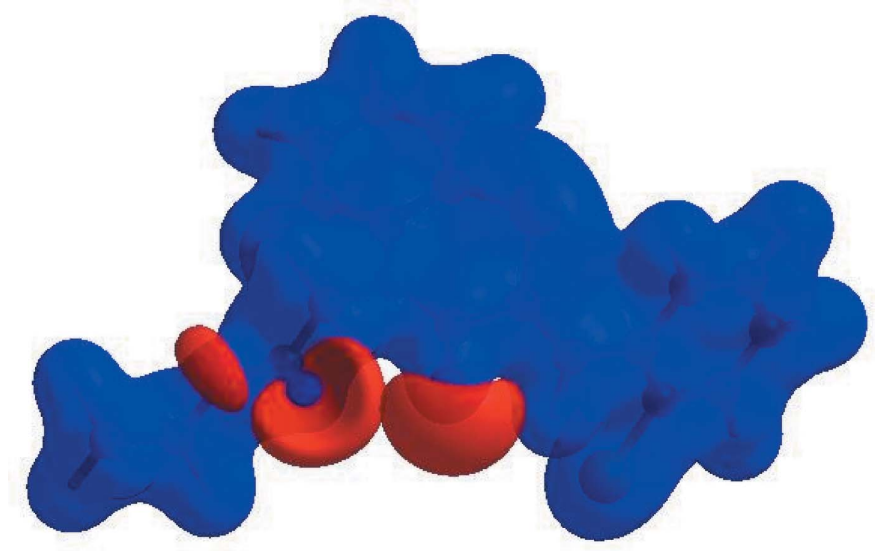

Figure 4

View of the three-dimensional Hirshfeld surface of the title compound plotted over electrostatic potential energy in the range -0.0500 to 0.0500 a.u. using the STO-3 G basis set at the Hartree-Fock level of theory. Hydrogen-bond donors and acceptors are shown as blue and red regions around the atoms corresponding to positive and negative potentials, respectively.
Table 2

Selected interatomic distances $(\AA)$.

\begin{tabular}{llll}
\hline $\mathrm{Cl} 1 \cdots \mathrm{C} 14^{\mathrm{i}}$ & $3.5363(9)$ & $\mathrm{O} 1 \cdots \mathrm{H} 12^{\mathrm{i}}$ & $2.560(9)$ \\
$\mathrm{C} 1 \cdots \mathrm{S} 1^{\mathrm{i}}$ & $3.7268(3)$ & $\mathrm{O} 1 \cdots \mathrm{H} 15^{\mathrm{ii}}$ & $2.400(8)$ \\
$\mathrm{C} 1 \cdots \mathrm{C} 10^{\mathrm{i}}$ & $3.5940(7)$ & $\mathrm{O} 2 \cdots \mathrm{H} 18 B$ & $2.545(11)$ \\
$\mathrm{C} 11 \cdots \mathrm{C} 15^{\mathrm{i}}$ & $3.4359(7)$ & $\mathrm{O} 2 \cdots \mathrm{H} 13^{\mathrm{i}}$ & $2.606(10)$ \\
$\mathrm{C} 1 \cdots \mathrm{H} 9$ & $2.674(8)$ & $\mathrm{O} 2 \cdots \mathrm{H} 18 A$ & $2.74(3)$ \\
$\mathrm{S} 1 \cdots \mathrm{N} 1$ & $3.0100(6)$ & $\mathrm{O} 3 \cdots \mathrm{H} 16 B^{\mathrm{vi}}$ & $2.666(8)$ \\
$\mathrm{S} 1 \cdots \mathrm{C} 15$ & $3.1748(8)$ & $\mathrm{C} 2 \cdots \mathrm{C} 17$ & $3.2932(10)$ \\
$\mathrm{S} 1 \cdots \mathrm{O} 1^{\mathrm{ii}}$ & $3.4189(6)$ & $\mathrm{C} 4 \cdots \mathrm{C} 14^{\mathrm{iii}}$ & $3.5882(12)$ \\
$\mathrm{S} 1 \cdots \mathrm{H} 15$ & $2.660(10)$ & $\mathrm{C} 2 \cdots \mathrm{H} 16 B$ & $2.621(8)$ \\
$\mathrm{S} 1 \cdots \mathrm{H} 5^{\mathrm{iii}}$ & $2.906(9)$ & $\mathrm{C} 4 \cdots \mathrm{H} 14^{\mathrm{iii}}$ & $2.826(10)$ \\
$\mathrm{O} 1 \cdots \mathrm{C} 17$ & $3.1263(9)$ & $\mathrm{C} 4 \cdots \mathrm{H} 12^{\mathrm{vii}}$ & $2.993(10)$ \\
$\mathrm{O} 1 \cdots \mathrm{C} 12^{\mathrm{i}}$ & $3.2141(10)$ & $\mathrm{C} 5 \cdots \mathrm{H} 12^{\mathrm{iii}}$ & $2.817(10)$ \\
$\mathrm{O} 1 \cdots \mathrm{C} 15^{\mathrm{ii}}$ & $3.2268(8)$ & $\mathrm{C} 7 \cdots \mathrm{H} 15$ & $2.937(9)$ \\
$\mathrm{O} 2 \cdots \mathrm{N} 1$ & $2.7902(7)$ & $\mathrm{C} 15 \cdots \mathrm{H} 16 A^{\mathrm{ii}}$ & $2.900(9)$ \\
$\mathrm{O} 2 \cdots \mathrm{C} 8$ & $3.2091(9)$ & $\mathrm{C} 16 \cdots \mathrm{H} 16 B^{\mathrm{vi}}$ & $2.987(9)$ \\
$\mathrm{O} 2 \cdots \mathrm{C} 1$ & $3.3715(8)$ & $\mathrm{C} 16 \cdots \mathrm{H} 2$ & $2.538(9)$ \\
$\mathrm{O} 2 \cdots \mathrm{C} 3^{\mathrm{iv}}$ & $3.3498(10)$ & $\mathrm{C} 17 \cdots \mathrm{H} 2$ & $2.696(9)$ \\
$\mathrm{O} 2 \cdots \mathrm{C} 2$ & $3.4103(9)$ & $\mathrm{H} 2 \cdots \mathrm{H} 16 B$ & $2.223(12)$ \\
$\mathrm{O} 1 \cdots \mathrm{H} 9$ & $2.516(9)$ & $\mathrm{H} 5 \cdots \mathrm{H} 12^{\mathrm{vii}}$ & $2.444(13)$ \\
$\mathrm{O} 1 \cdots \mathrm{H} 16 A$ & $2.376(9)$ & $\mathrm{H} 5 \cdots \mathrm{H} 15^{\mathrm{iii}}$ & $2.509(12)$ \\
$\mathrm{O} 1 \cdots \mathrm{H} 4^{\mathrm{v}}$ & $2.806(11)$ & $\mathrm{H} 16 B \cdots \mathrm{H} 16 B^{\mathrm{vi}}$ & $2.381(13)$ \\
\hline
\end{tabular}

Symmetry codes: (i) $-x+1, y-\frac{1}{2},-z+\frac{1}{2}$; (ii) $-x+1,-y+1,-z+1$; $\quad$ (iii) $-x+1,-y+2,-z+1$; (iv) $-x, y-\frac{1}{2},-z+\frac{1}{2}$; (v) $x, y-1, z$; (vi) $-x,-y+1,-z+1$; (vii) $-x+1, y+\frac{1}{2},-z+\frac{1}{2}$.

shown in Fig. 4. Here the blue regions indicate positive electrostatic potential (hydrogen-bond donors), while the red regions indicate negative electrostatic potential (hydrogenbond acceptors). The shape-index of the HS is a tool to visualize the $\pi-\pi$ stacking by the presence of adjacent red and blue triangles; if there are no adjacent red and/or blue triangles, then there are no $\pi-\pi$ interactions. Fig. 5 clearly suggests that there are no $\pi-\pi$ interactions in (I).

The overall two-dimensional fingerprint plot, Fig. $6 a$, and those delineated into $\mathrm{H} \cdots \mathrm{H}, \mathrm{H} \cdots \mathrm{C} / \mathrm{C} \cdots \mathrm{H}, \mathrm{H} \cdots \mathrm{O} / \mathrm{O} \cdots \mathrm{H}$, $\mathrm{H} \cdots \mathrm{Cl} / \mathrm{Cl} \cdots \mathrm{H}, \quad \mathrm{C} \cdots \mathrm{Cl} / \mathrm{Cl} \cdots \mathrm{C}, \mathrm{H} \cdots \mathrm{S} / \mathrm{S} \cdots \mathrm{H}, \quad \mathrm{S} \cdots \mathrm{Cl} / \mathrm{Cl} \cdots \mathrm{S}$ and $\mathrm{C}$.. C contacts (McKinnon et al., 2007) are illustrated in Fig. $6 b-i$, respectively, together with their relative contributions to the Hirshfeld surface. The most important interaction is $\mathrm{H} \cdots \mathrm{H}$ (Table 2 ) contributing $37.5 \%$ to the overall crystal

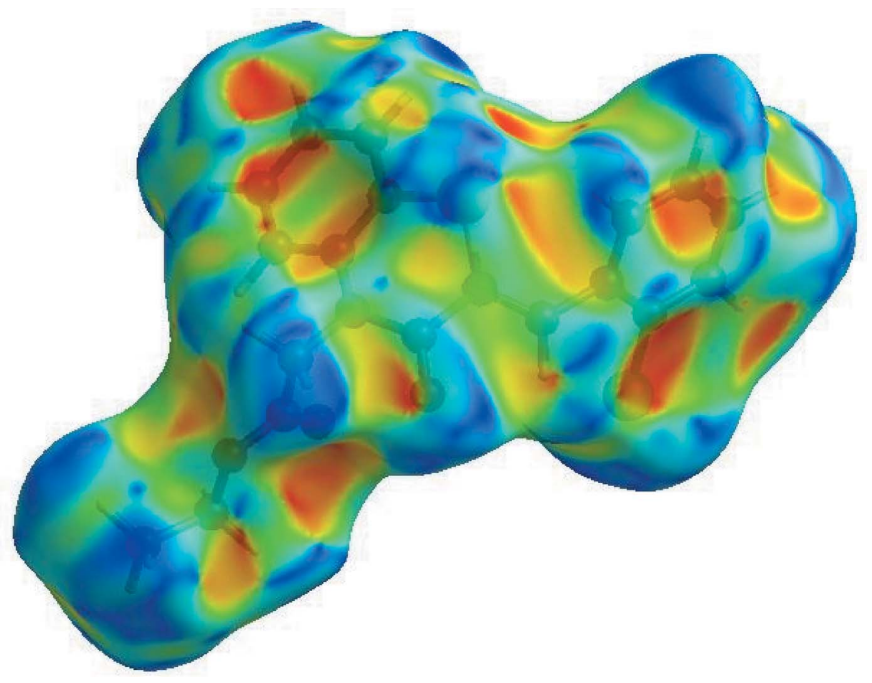

Figure 5

Hirshfeld surface of the title compound plotted over shape-index. 

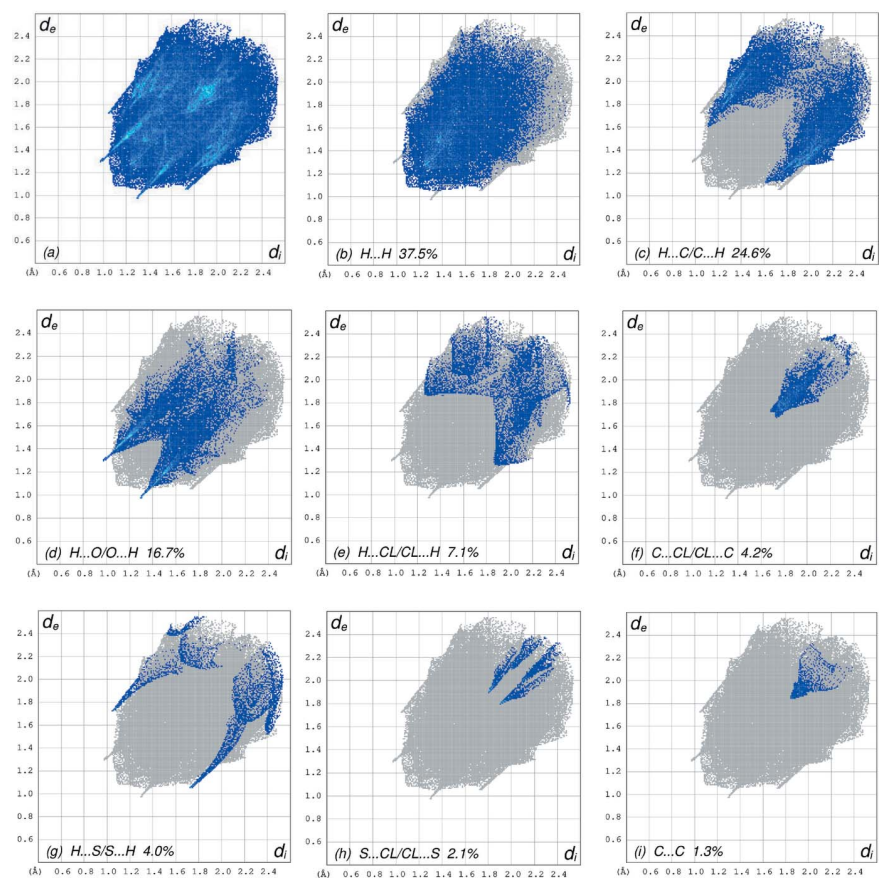

Figure 6

The full two-dimensional fingerprint plots for the title compound, showing (a) all interactions, and delineated into $(b) \mathrm{H} \cdots \mathrm{H},(c) \mathrm{H} \cdots \mathrm{C} /$ $\mathrm{C} \cdots \mathrm{H},(d) \mathrm{H} \cdots \mathrm{O} / \mathrm{O} \cdots \mathrm{H},($ e $) \mathrm{H} \cdots \mathrm{Cl} / \mathrm{Cl} \cdots \mathrm{H},(f) \mathrm{C} \cdots \mathrm{Cl} / \mathrm{Cl} \cdots \mathrm{C},(g)$ $\mathrm{H} \cdots \mathrm{S} / \mathrm{S} \cdots \mathrm{H},(h) \mathrm{S} \cdots \mathrm{Cl} / \mathrm{Cl} \cdots \mathrm{S}$ and $(i) \mathrm{C} \cdots \mathrm{C}$ interactions. The $d_{\mathrm{i}}$ and $d_{\mathrm{e}}$ values are the closest internal and external distances (in $\AA$ ) from given points on the Hirshfeld surface.

packing, which is reflected in Fig. $6 b$ as widely scattered points of high density due to the large hydrogen-atom content of the molecule with the tip at $d_{\mathrm{e}}=d_{\mathrm{i}}=1.10 \AA$. The pair of characteristic wings in the fingerprint plot delineated into $\mathrm{H} \cdots \mathrm{C} /$ C. $\cdot \mathrm{H}$ contacts (Table 2, Fig. $6 c ; 24.6 \%$ contribution to the HS), have tips at $d_{\mathrm{e}}+d_{\mathrm{i}}=2.72 \AA$. The $\mathrm{H} \cdots \mathrm{O} / \mathrm{O} \cdots \mathrm{H}$ contacts

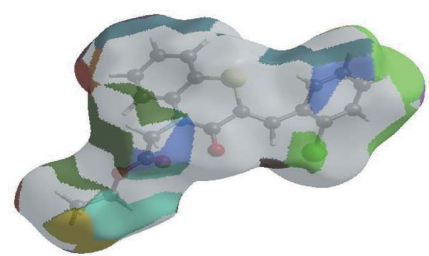

(a)

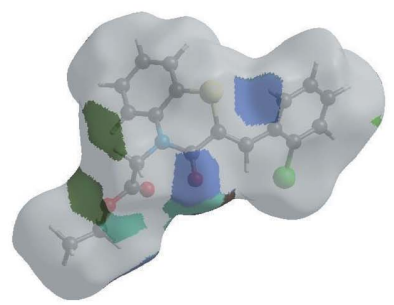

(c)

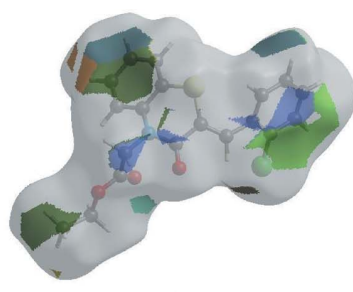

(b)

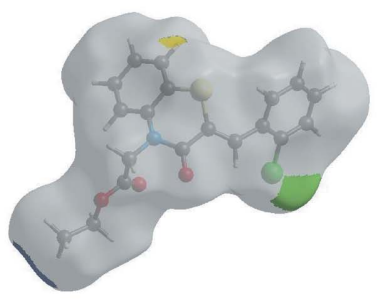

(d)
Figure 7

Hirshfeld surface representations with the function $d_{\text {norm }}$ plotted onto the surface for $(a) \mathrm{H} \cdots \mathrm{H},(b) \mathrm{H} \cdots \mathrm{C} / \mathrm{C} \cdots \mathrm{H},(c) \mathrm{H} \cdots \mathrm{O} / \mathrm{O} \cdots \mathrm{H}$ and $(d)$ $\mathrm{H} \cdots \mathrm{Cl} / \mathrm{Cl} \cdots \mathrm{H}$ interactions.
(Table 1, Fig. $6 d$ ) with a $16.7 \%$ contribution to the HS have a symmetric distribution of points with the tips at $d_{\mathrm{e}}+d_{\mathrm{i}}=$ $2.27 \AA$. The scattered points in the wings in the fingerprint plot delineated into $\mathrm{H} \cdots \mathrm{Cl} / \mathrm{Cl} \cdots \mathrm{H}$, Fig. $6 e$, contacts $(7.1 \%$ contribution) have the tips at $d_{\mathrm{e}}+d_{\mathrm{i}}=3.14 \AA$. The $\mathrm{C} \cdots \mathrm{Cl} /$ $\mathrm{Cl} \cdots \mathrm{C}$ contacts, Fig. $6 f$, with $4.2 \%$ contribution to the HS have an arrow-shaped distribution of points of split small wings with the tips at $d_{\mathrm{e}}+d_{\mathrm{i}}=3.41 \AA$. The pair of spikes in the fingerprint plot delineated into $\mathrm{H} \cdots \mathrm{S} / \mathrm{S} \cdots \mathrm{H}$, Fig. $6 g$, contacts $(4.0 \%$ contribution) have tips at $d_{\mathrm{e}}+d_{\mathrm{i}}=2.78 \AA$. The pair of characteristic wings in the fingerprint plot delineated into $\mathrm{S} \cdots \mathrm{Cl} /$ $\mathrm{Cl} \cdots \mathrm{S}$ contacts, Fig. $6 h,(2.1 \%$ contribution $)$ has the tips at $d_{\mathrm{e}}$ $+d_{\mathrm{i}}=3.70 \AA$ A. Finally, the C..C contacts, Fig. $6 i,(1.3 \%$ contribution) have an arrow-shaped distribution of points with the tip at $d_{\mathrm{e}}=d_{\mathrm{i}}=1.85 \AA$.

The Hirshfeld surface representations with the function $d_{\text {norm }}$ plotted onto the surface are shown for the $\mathrm{H} \cdots \mathrm{H}$, $\mathrm{H} \cdots \mathrm{C} / \mathrm{C} \cdots \mathrm{H}, \mathrm{H} \cdots \mathrm{O} / \mathrm{O} \cdots \mathrm{H}$ and $\mathrm{H} \cdots \mathrm{Cl} / \mathrm{Cl} \cdots \mathrm{H}$ interactions in Fig. 7a-d, respectively.

The Hirshfeld surface analysis confirms the importance of $\mathrm{H}$-atom contacts in establishing the packing. The large number of $\mathrm{H} \cdots \mathrm{H}, \mathrm{H} \cdots \mathrm{C} / \mathrm{C} \cdots \mathrm{H}$ and $\mathrm{H} \cdots \mathrm{O} / \mathrm{O} \cdots \mathrm{H}$ interactions suggest that van der Waals interactions and hydrogen bonding play the major roles in the crystal packing (Hathwar et al., 2015).

\section{Interaction energy calculations}

The intermolecular interaction energies were calculated using the CE-B3LYP/6-31G(d,p) energy model available in Crystal Explorer 17.5 (Turner et al., 2017), where a cluster of molecules is generated by applying crystallographic symmetry operations with respect to a selected central molecule within a default radius of $3.8 \AA$ (Turner et al., 2014). The total intermolecular energy $\left(E_{\text {tot }}\right)$ is the sum of electrostatic $\left(E_{\text {ele }}\right)$, polarization $\left(E_{\mathrm{pol}}\right)$, dispersion $\left(E_{\mathrm{dis}}\right)$ and exchange-repulsion $\left(E_{\text {rep }}\right)$ energies (Turner et al., 2015) with scale factors of 1.057, $0.740,0.871$ and 0.618 , respectively (Mackenzie et al., 2017). Hydrogen-bonding interaction energies (in $\mathrm{kJ} \mathrm{mol}^{-1}$ ) were calculated to be $-20.3\left(E_{\text {ele }}\right),-5.9\left(E_{\mathrm{pol}}\right),-48.7\left(E_{\mathrm{dis}}\right), 48.5$

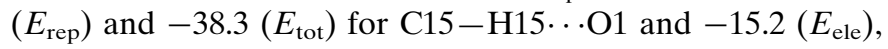
$-4.1\left(E_{\mathrm{pol}}\right),-42.2\left(E_{\mathrm{dis}}\right), 41.3\left(E_{\mathrm{rep}}\right)$ and $-30.3\left(E_{\mathrm{tot}}\right)$ for $\mathrm{C} 12-\mathrm{H} 12 \cdots \mathrm{O} 1$.

\section{DFT calculations}

The optimized structure of the title compound, (I), in the gas phase was generated theoretically via density functional theory (DFT) using the standard B3LYP functional and 6-311 G(d,p) basis-set calculations (Becke, 1993) as implemented in GAUSSIAN 09 (Frisch et al., 2009). The theoretical and experimental results are in good agreement (Table 3). The highest-occupied molecular orbital (HOMO), acting as an electron donor, and the lowest-unoccupied molecular orbital (LUMO), acting as an electron acceptor, are important parameters for quantum chemistry. When the energy gap is small, the molecule is highly polarizable and has high chemical 
Table 3

Comparison of selected (X-ray and DFT) geometric data $\left(\AA{ }^{\circ}\right)$.

\begin{tabular}{lll}
\hline Bonds/angles & X-ray & B3LYP/6-311G(d,p) \\
\hline Cl1-C11 & $1.741(2)$ & 1.83593 \\
S1-C6 & $1.755(2)$ & 1.83362 \\
S1-C7 & $1.757(2)$ & 1.79349 \\
O1-C8 & $1.224(2)$ & 1.26839 \\
O2-C17 & $1.200(2)$ & 1.23993 \\
O3-C17 & $1.335(2)$ & 1.36867 \\
O3-C18 & $1.462(3)$ & 1.48321 \\
N1-C8 & $1.381(2)$ & 1.40044 \\
N1-C1 & $1.417(2)$ & 1.41683 \\
N1-C16 & $1.452(2)$ & 1.47008 \\
C6-S1-C7 & & \\
C17-O3-C18 & $98.19(9)$ & 99.41730 \\
C8-N1-C1 & $116.60(16)$ & 116.97676 \\
C8-N1-C16 & $124.52(15)$ & 125.49531 \\
C1-N1-C16 & $115.56(16)$ & 118.02066 \\
C2-C1-N1 & $118.47(16)$ & 121.23845 \\
C2-C1-C6 & $121.41(17)$ & 117.94010 \\
C6-C1-N1 & $118.60(18)$ & 120.81444 \\
O1-C8-N1 & $120.00(17)$ & 120.12402 \\
O1-C8-C7 & $120.36(17)$ & 120.12402 \\
N1-C8-C7 & $121.99(17)$ & 117.79908 \\
\hline
\end{tabular}

reactivity. The DFT calculations provide some important information on the reactivity and site selectivity of the molecular framework. $E_{\mathrm{HOMO}}$ and $E_{\mathrm{LuMO}}$ clarify the inevitable charge-exchange collaboration inside the studied material, electronegativity $(\chi)$, hardness $(\eta)$, potential $(\mu)$, electrophilicity $(\omega)$ and softness $(\sigma)$ are recorded in Table 4 . The parameters $\eta$ and $\sigma$ are significant for the evaluation of both the reactivity and stability. The electron transition from the HOMO to the LUMO energy level is shown in Fig. 8. The HOMO and LUMO are localized in the plane extending from the whole 2-[(2Z)-2-(2-chlorobenzylidene)-3-oxo-3,4-dihydro$2 \mathrm{H}$-1,4-benzothiazin-4-yl]acetate ring. The energy band gap [ $\left.\Delta E=E_{\mathrm{LUMO}}-E_{\mathrm{HOMO}}\right]$ of the molecule is $4.3346 \mathrm{eV}$, and the frontier molecular orbital energies, $E_{\mathrm{HOMO}}$ and $E_{\mathrm{LUMO}}$ are -5.2696 and $-0.9347 \mathrm{eV}$, respectively.

\section{Database survey}

A search of the Cambridge Structural Database (Version 5.38; Groom et al., 2016) with the fragment (II) yielded 16 hits. The largest group is that for (III) with $R=\mathrm{Ph}$ and $R^{\prime}=A$ (WUFGIP; Sebbar et al., 2015b), $\mathrm{CH}_{2} \mathrm{COOH}$ (APAJUY; Sebbar et al., 2016a), $\left(\mathrm{CH}_{2}\right)_{17} \mathrm{CH}_{3}$ (CARCEG; Sebbar et al., 2017a), n-Bu (JOGVOS; Sebbar et al., 2014a), $\mathrm{CH}_{2} \mathrm{C} \equiv \mathrm{CH}$ (COGRUN; Sebbar et al., 2014b), $R=\mathrm{Ph}$ and $R^{\prime}=B$ (EVIYIT; (Sebbar et al., 2016b), $\mathrm{CH}_{2} \mathrm{COOCH}_{3}$ (ICAJOL; Zerzouf et al., 2001), $R=\mathrm{Ph}$ and $R^{\prime}=C$ (JADPOW; Ellouz et al., 2015) and $R=\mathrm{Ph}$ and $R^{\prime}=D$ (OBITUR; Sebbar et al., 2016c). The remainder have $R=4-\mathrm{ClC}_{6} \mathrm{H}_{4}$ and $R^{\prime}=$ bz (OMEGEU; Ellouz et al., 2016c), $n$-Bu (PAWCIC; Ellouz et al., 2017a) and $R=4$ $\mathrm{ClC}_{6} \mathrm{H}_{4}$ and $R^{\prime}=B$ (YANHAZ; Ellouz et al., 2017b) or $R=2$ $\mathrm{ClC}_{6} \mathrm{H}_{4}$, and $R^{\prime}=\mathrm{CH}_{2} \mathrm{C} \equiv \mathrm{CH}$ (SAVTUH; Sebbar et al., 2017b) or $R=4-\mathrm{FC}_{6} \mathrm{H}_{4}$ and $R^{\prime}=\mathrm{CH}_{2} \mathrm{C} \equiv \mathrm{CH}$ (WOCFUS; Hni et al., $2019 a$ ) or $R=2,4-\mathrm{Cl}_{2} \mathrm{C}_{6} \mathrm{H}_{3}$ and $R^{\prime}=B$ (DOHZUY; Hni et al.,
Table 4

Calculated energies.

\begin{tabular}{rl}
\hline Molecular Energy (a.u.) (eV) & Compound (I) \\
\hline Total Energy, $T E(\mathrm{eV})$ & -50964 \\
$\mathrm{E}_{\mathrm{HOMO}}(\mathrm{eV})$ & -5.2696 \\
$\mathrm{E}_{\mathrm{LUMO}}(\mathrm{eV})$ & -0.9347 \\
Gap, $\Delta E(\mathrm{eV})$ & 4.3346 \\
Dipole moment, $\mu($ Debye $)$ & 5.6841 \\
Ionization potential, $I(\mathrm{eV})$ & 5.2696 \\
Electron affinity, $A$ & 0.9347 \\
Electronegativity, $\chi$ & 3.1019 \\
Hardness, $\eta$ & 2.1673 \\
Electrophilicity index, $\omega$ & 2.2198 \\
Softness, $\sigma$ & 0.4614 \\
Fraction of electron transferred, $\Delta N$ & 0.8993
\end{tabular}
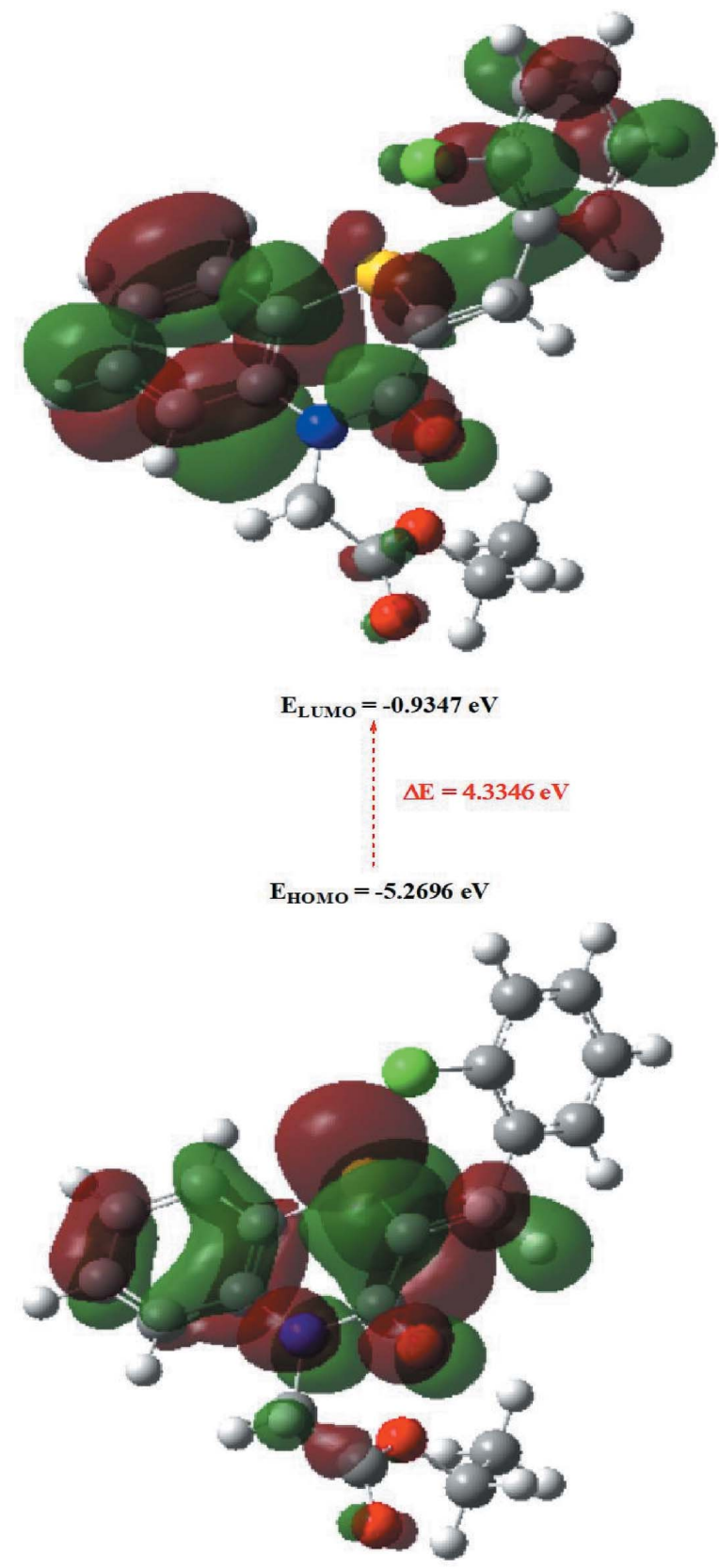

Figure 8

The energy band gap of the title compound, (I). 
$2019 b, \mathrm{CH}_{2} \mathrm{CH}_{2} \mathrm{CN}$ (POHPOU; Sebbar et al., 2019a). In the majority of these, the thiazine ring is significantly folded about the $\mathrm{S} \cdots \mathrm{N}$ axis with dihedral angles between the two $\mathrm{S} / \mathrm{C} / \mathrm{C} / \mathrm{N}$ planes ranging from $\mathrm{ca} 35^{\circ}$ (JADPOW and WUFGIP) to $\mathrm{ca}$ $27^{\circ}$ (COGRUN and WOCFUS). Two others have intermediate values of $c a 15^{\circ}$ (POHPOU) and $9^{\circ}$ (DOHZUY), while in the last three, the thiazine ring is nearly flat with a dihedral angle of $c a 4^{\circ}$ (EVIYIT, OBITUR and OMEGEU). It is not immediately obvious what the reasons are for these nearly planar rings, but it may be in part due to packing considerations since in these last three molecules, the substituents on the thiazine rings do not hold the benzothiazine moieties as far apart as in the other cases, so that $\pi$-stacking interactions between the benzo portions can bring them close together and flatten out the rings.<smiles>C/C=C1/Sc2ccccc2N(CC)C1=O</smiles>

(II)<smiles>CC1CC(c2ccccc2)=NO1</smiles>

A<smiles>CCOC(=O)n1nncc1C</smiles><smiles>[R]C=C1Sc2ccccc2N([R])C1=O</smiles>

(III)<smiles>CCN1CCOC1=O</smiles><smiles>Cc1cnnn1C(=O)c1ccccc1</smiles>

\section{Antibacterial activity}

To compare and analyse the antibacterial behaviour contributed by (I), and commercial antibiotics such as Chloramphenicol (Chlor) and Ampicillin (Amp), we have tested the title compound, (I), against Staphylococcus aureus (ATCC25923), Escherichia coli (ATTC-25922) and Pseudomonas aeruginosa (ATCC-27853) strains of bacteria using the diffusion disk method to evaluate the applicability of (I) as an antibacterial agent (Mabkhot et al., 2016; Hoffmann et al., 2017). Fig. 9 summarizes the diameter of inhibition (mm) values of (I) and commercial antibiotics chloramphenicol (Chlor) and ampicillin (Amp) against Staphylococcus aureus, Escherichia coli and Pseudomonas aeruginosa. The determination of the minimum inhibition concentration (MIC) values of the sample (I) against the bacteria are presented in Table 5. The results of antibacterial activity of the product tested showed the best activity with MIC value of $21 \mu \mathrm{g} \mathrm{mL}^{-1}$ and different degrees of growth inhibition against the bacteria tested. It is clear that there is a significant enhancement and a
Table 5

Minimal inhibitory concentration [MIC $\left(\mu \mathrm{g} \mathrm{m} L^{-1}\right)$ ].

ATCC-25923 = Staphylococcus aureus, ATTC-25922 = Escherichia coli, ATCC-27853 $=$ Pseudomonas aeruginosa, Chlor $=$ chloramphenicol and Amp $=$ ampicillin.

\begin{tabular}{llll}
\hline Product & ATCC-25923 & ATTC-25922 & ATCC-27853 \\
\hline (I) & 21 & 21 & 21 \\
Chlor & 58 & 58 & 58 \\
Amp & 12 & 12 & 12 \\
DMSO & 0 & 0 & 0 \\
\hline
\end{tabular}

strong antibacterial activity associated with sample (I), as compared to commercial antibiotics. In addition, the maximum effect of (I) was recorded against Staphylococcus aureus (diameter of inhibition $16.4 \mathrm{~mm}$ ). Chloramphenicol and ampicillin present a moderate antibacterial activity diameter of inhibition $22.6 \mathrm{~mm}$ and $11.75 \mathrm{~mm}$, respectively, and no zone inhibition was observed with DMSO. On one hand, the chemical structure of (I) can explain this biologic effect. The mechanism of action of (I) is not attributable to one specific mechanism, but there are several targets in the cell: degradation of the cell wall, damage to membrane proteins, damage to cytoplasmic membrane, leakage of cell contents and coagulation of cytoplasm. On the other hand, it should be noted that the derivatives functionalized by ester groups and benzene rings have the highest antibacterial coefficient (92\% of pathogenic bacteria are sensitive). This study is expected to include anti-inflammatory, antifungal, anti-parasitic and anti-cancer activities, because the literature gives a lot of interesting results on these topics. Some other types of bacteria may possibly be tested by employing the same method so as to eventually generalize the suggested investigation method (Alderman \& Smith, 2001).

\section{Synthesis and crystallization}

To a solution of 2-(2-chlorobenzylidene)-3,4-dihydro-2H-1,4benzothiazin-3-one $(0.57 \mathrm{~g}, 2 \mathrm{mmol})$, potassium carbonate

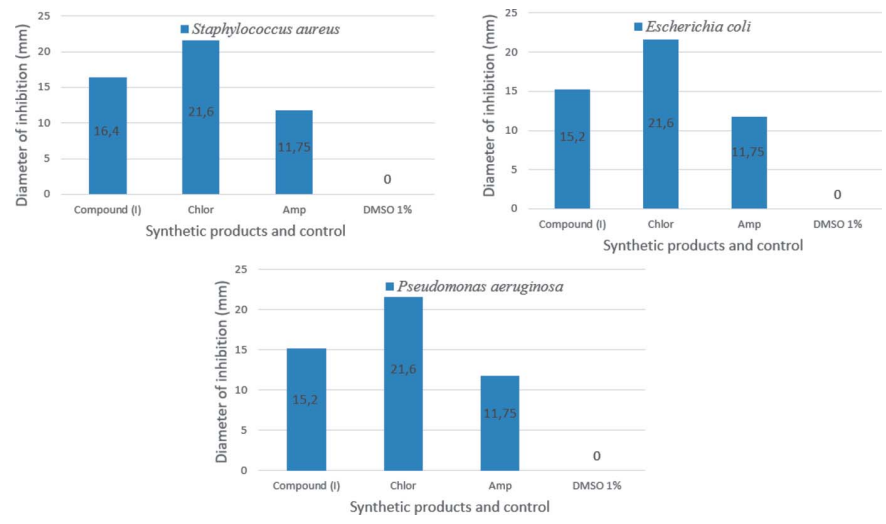

Figure 9

Antibacterial activity of the title compound, (I), and the commercial antibiotics chloramphenicol (Chlor) and ampicillin (Amp) against the bacteria Staphylococcus aureus, Escherichia coli and Pseudomonas aeruginosa. 
$(4 \mathrm{mmol})$ and tetra $n$-butyl ammonium bromide $(0.2 \mathrm{mmol})$ in DMF $(14 \mathrm{ml})$ was added ethyl chloroacetate $(0.49 \mathrm{~g}, 4 \mathrm{mmol})$. Stirring was continued at room temperature for $14 \mathrm{~h}$. The mixture was filtered and the solvent removed. The residue was extracted with water. The organic compound was chromatographed on a column of silica gel with ethyl acetate-hexane (8:2) as eluent. Colourless crystals of the title compound, (I), were isolated when the solvent was allowed to evaporate (yield: 66\%).

\section{Refinement}

Crystal data, data collection and structure refinement details are summarized in Table 6. Hydrogen atoms were located in a difference-Fourier map and refined freely. The model was refined as a two-component twin with twin law $\overline{1} 00,0 \overline{1} 0,00 \overline{1}$ and a refined BASF parameter of 0.34961 (5).

\section{Funding information}

The support of NSF-MRI grant No. 1228232 for the purchase of the diffractometer and Tulane University for support of the Tulane Crystallography Laboratory are gratefully acknowledged. TH is grateful to the Hacettepe University Scientific Research Project Unit (grant No. 013 D04 602 004).

\section{References}

Alderman, D. \& Smith, P. (2001). Aquaculture, 196, 211-243.

Armenise, D., Muraglia, M., Florio, M. A., Laurentis, N. D., Rosato, A., Carrieri, A., Corbo, F. \& Franchini, C. (2012). Mol. Pharmacol. Mol. Pharmacol. 50, 1178-1188.

Becke, A. D. (1993). J. Chem. Phys. 98, 5648-5652.

Brandenburg, K. \& Putz, H. (2012). DIAMOND, Crystal Impact GbR, Bonn, Germany.

Bruker (2016). APEX3, SADABS and SAINT. Bruker AXS Inc., Madison, Wisconsin, USA.

Ellouz, M., Elmsellem, H., Sebbar, N. K., Steli, H., Al Mamari, K., Nadeem, A., Ouzidan, Y., Essassi, E. M., Abdel-Rahaman, I. \& Hristov, P. (2016b). J. Mater. Environ. Sci. 7, 2482-2497.

Ellouz, M., Sebbar, N. K., Boulhaoua, M., Essassi, E. M. \& Mague, J. T. (2017a). IUCr Data 2, x170646.

Ellouz, M., Sebbar, N. K., Elmsellem, H., Lakhrissi, B., Mennane, Z., Charof, R., Urrutigoity, M. \& Essassi, E. M. (2019). Sci. Study Res. 20, 563-574.

Ellouz, M., Sebbar, N. K., Elmsellem, H., Steli, H., Fichtali, I., Mohamed, A. M. M., Mamari, K. A., Essassi, E. M. \& AbdelRahaman, I. (2016a). J. Mater. Environ. Sci. 7, 2806-2819.

Ellouz, M., Sebbar, N. K., Essassi, E. M., Ouzidan, Y. \& Mague, J. T. (2015). Acta Cryst. E71, o1022-o1023.

Ellouz, M., Sebbar, N. K., Essassi, E. M., Ouzidan, Y., Mague, J. T. \& Zouihri, H. (2016c). IUCrData, 1, x160764.

Ellouz, M., Sebbar, N. K., Fichtali, I., Ouzidan, Y., Mennane, Z., Charof, R., Mague, J. T., Urrutigoïty, M. \& Essassi, E. M. (2018). Chem. Cent. J. 12, 123.

Ellouz, M., Sebbar, N. K., Ouzidan, Y., Kaur, M., Essassi, E. M. \& Jasinski, J. P. (2017b). IUCrData, 2, x170870.

Frisch, M. J., Trucks, G. W., Schlegel, H. B., Scuseria, G. E., Robb, M. A., Cheeseman, J. R., et al. (2009). GAUSSIAN 09. Gaussian Inc., Wallingford, CT, USA.

Gowda, J., Khader, A. M. A., Kalluraya, B., Shree, P. \& Shabaraya, A. R. (2011). Eur. J. Med. Chem. 46, 4100-4106.

Table 6

Experimental details.

Crystal data

Chemical formula

$M_{\mathrm{r}}$

Crystal system, space group

Temperature (K)

$a, b, c(\AA)$

$\beta\left({ }^{\circ}\right)$

$V\left(\AA^{3}\right)$

$Z$

Radiation type

$\mu\left(\mathrm{mm}^{-1}\right)$

Crystal size (mm)

Data collection

Diffractometer

Absorption correction

$T_{\min }, T_{\max }$

No. of measured, independent and observed $[I>2 \sigma(I)]$ reflections

$R_{\text {int }}$

$(\sin \theta / \lambda)_{\max }\left(\AA^{-1}\right)$

Refinement

$R\left[F^{2}>2 \sigma\left(F^{2}\right)\right], w R\left(F^{2}\right), S$

No. of reflections

No. of parameters

$\mathrm{H}$-atom treatment

$\Delta \rho_{\max }, \Delta \rho_{\min }\left(\mathrm{e} \AA^{-3}\right)$

Computer programs: APEX3 and SAINT (Bruker, 2016), CELL_NOW (Sheldrick, 2008a), SHELXT (Sheldrick, 2015a), SHELXL2018 (Sheldrick, 2015b), DIAMOND (Brandenburg \& Putz, 2012) and SHELXTL (Sheldrick, 2008b).

Groom, C. R., Bruno, I. J., Lightfoot, M. P. \& Ward, S. C. (2016). Acta Cryst. B72, 171-179.

Gupta, R. R., Kumar, R. \& Gautam, R. K. (1985). J. Fluor. Chem. 28, 381-385.

Gupta, V. \& Gupta, R. R. (1991). J. Prakt. Chem. 333, 153-156.

Hathwar, V. R., Sist, M., Jørgensen, M. R. V., Mamakhel, A. H., Wang, X., Hoffmann, C. M., Sugimoto, K., Overgaard, J. \& Iversen, B. B. (2015). IUCrJ, 2, 563-574.

Hirshfeld, H. L. (1977). Theor. Chim. Acta, 44, 129-138.

Hni, B., Sebbar, N. K., Hökelek, T., El Ghayati, L., Bouzian, Y., Mague, J. T. \& Essassi, E. M. (2019b). Acta Cryst. E75, 593-599.

Hni, B., Sebbar, N. K., Hökelek, T., Ouzidan, Y., Moussaif, A., Mague, J. T. \& Essassi, E. M. (2019a). Acta Cryst. E75, 372-377.

Hoffmann, K., Wiśniewska, J., Wojtczak, A., Sitkowski, J., Denslow, A., Wietrzyk, J., Jakubowski, M. \& Łakomska, I. (2017). J. Inorg. Biochem. 172, 34-45.

Jayatilaka, D., Grimwood, D. J., Lee, A., Lemay, A., Russel, A. J., Taylor, C., Wolff, S. K., Cassam-Chenai, P. \& Whitton, A. (2005). TONTO - A System for Computational Chemistry. Available at: http://hirshfeldsurface.net/

Mabkhot, Y. N., Alatibi, F., El-Sayed, N. N. E., Kheder, N. A. \& AlShowiman, S. S. (2016). Molecules, 21, 1036.

Mackenzie, C. F., Spackman, P. R., Jayatilaka, D. \& Spackman, M. A. (2017). IUCrJ, 4, 575-587.

Malagu, K., Boustie, J., David, M., Sauleau, J., Amoros, M., Girre, R. L. \& Sauleau, A. (1998). Pharm. Pharmacol. Commun. 4, 5760.

McKinnon, J. J., Jayatilaka, D. \& Spackman, M. A. (2007). Chem. Commun. pp. 3814-3816.

Munirajasekar, D., Himaja, M. \& Sunil, M. (2011). Int. Res. J. Pharm. 2, 114-117.

Sabatini, S., Kaatz, G. W., Rossolini, G. M., Brandini, D. \& Fravolini, A. (2008). J. Med. Chem. 51, 4321-4330. 
Sebbar, N. K., El Fal, M., Essassi, E. M., Saadi, M. \& El Ammari, L. (2014a). Acta Cryst. E70, o686.

Sebbar, N. K., Ellouz, M., Boulhaoua, M., Ouzidan, Y., Essassi, M. \& Mague, J. T. (2016c). IUCrData, 1, x161823.

Sebbar, N. K., Ellouz, M., Essassi, E. M., Ouzidan, Y. \& Mague, J. T. (2015a). Acta Cryst. E71, o999.

Sebbar, N. K., Ellouz, M., Essassi, E. M., Saadi, M. \& El Ammari, L. (2015b). Acta Cryst. E71, o423-o424.

Sebbar, N. K., Ellouz, M., Lahmidi, S., Hlimi, F., Essassi, E. M. \& Mague, J. T. (2017a). IUCrData, 2, x170695.

Sebbar, N. K., Ellouz, M., Mague, J. T., Ouzidan, Y., Essassi, E. M. \& Zouihri, H. (2016a). IUCrData, 1, x160863.

Sebbar, N. K., Ellouz, M., Ouzidan, Y., Kaur, M., Essassi, E. M. \& Jasinski, J. P. (2017b). IUCrData, 2, x170889.

Sebbar, N. K., Hni, B., Hökelek, T., Jaouhar, A., Labd Taha, M., Mague, J. T. \& Essassi, E. M. (2019a). Acta Cryst. E75, 721-727.

Sebbar, N. K., Hni, B., Hökelek, T., Labd Taha, M., Mague, J. T., El Ghayati, L. \& Essassi, E. M. (2019b). Acta Cryst. E75, 1650-1656.

Sebbar, N. K., Mekhzoum, M., Essassi, E. M., Zerzouf, A., Talbaoui, A., Bakri, Y., Saadi, M. \& Ammari, L. E. (2016b). Res. Chem. Intermed. 42, 6845-6862.

Sebbar, N. K., Zerzouf, A., Essassi, E. M., Saadi, M. \& El Ammari, L. (2014b). Acta Cryst. E70, o614.

Sheldrick, G. M. (2008a). CELL_NOW, University of Göttingen, Göttingen, Germany.

Sheldrick, G. M. (2008b). Acta Cryst. A64, 112-122.

Sheldrick, G. M. (2009). TWINABS, University of Göttingen, Göttingen, Germany.

Sheldrick, G. M. (2015a). Acta Cryst. A71, 3-8.

Sheldrick, G. M. (2015b). Acta Cryst. C71, 3-8.
Spackman, M. A. \& Jayatilaka, D. (2009). CrystEngComm, 11, 19-32. Spackman, M. A., McKinnon, J. J. \& Jayatilaka, D. (2008). CrystEngComm, 10, 377-388.

Tawada, H., Sugiyama, Y., Ikeda, H., Yamamoto, Y. \& Meguro, K. (1990). Chem. Pharm. Bull. 38, 1238-1245.

Trapani, G., Reho, A., Morlacchi, F., Latrofa, A., Marchini, P., Venturi, F. \& Cantalamessa, F. (1985). Farmaco Ed. Sci. 40, 369376.

Turner, M. J., Grabowsky, S., Jayatilaka, D. \& Spackman, M. A. (2014). J. Phys. Chem. Lett. 5, 4249-4255.

Turner, M. J., McKinnon, J. J., Wolff, S. K., Grimwood, D. J., Spackman, P. R., Jayatilaka, D. \& Spackman, M. A. (2017). CrystalExplorer17. The University of Western Australia.

Turner, M. J., Thomas, S. P., Shi, M. W., Jayatilaka, D. \& Spackman, M. A. (2015). Chem. Commun. 51, 3735-3738.

Venkatesan, P., Thamotharan, S., Ilangovan, A., Liang, H. \& Sundius, T. (2016). Spectrochim. Acta Part A, 153, 625-636.

Vidal, A., Madelmont, J. C. \& Mounetou, E. A. (2006). Synthesis, pp. 591-593.

Vijay, V. D. \& Rahul, P. G. (2016). Arabian J. Chem. 9, S225-S229.

Warren, B. K. \& Knaus, E. E. (1987). Eur. J. Med. Chem. 22, 411415.

Zerzouf, A., Salem, M., Essassi, E. M. \& Pierrot, M. (2001). Acta Cryst. E57, o498-o499.

Zia-ur-Rehman, M., Choudary, J. A., Elsegood, M. R. J., Siddiqui, H. L. \& Khan, K. M. (2009). Eur. J. Med. Chem. 44, 1311-1316.

Zięba, A., Latocha, M., Sochanik, A., Nycz, A. \& Kuśmierz, D. (2016). Molecules, 21, 1455.

Zięba, A., Sochanik, A., Szurko, A., Rams, M., Mrozek, A. \& Cmoch, P. (2010). Eur. J. Med. Chem. 45, 4733-4739. 


\section{supporting information}

Acta Cryst. (2020). E76, 629-636 [https://doi.org/10.1107/S2056989020004119]

Crystal structure, Hirshfeld surface analysis and interaction energy, DFT and antibacterial activity studies of ethyl 2-[(2Z)-2-(2-chlorobenzylidene)-3-oxo-3,4dihydro-2H-1,4-benzothiazin-4-yl]acetate

Ghizlane Sebbar, Ellouz Mohamed, Tuncer Hökelek, Joel T. Mague, Nada Kheira Sebbar, El Mokhtar Essassi and Bouchra Belkadi

Computing details

Data collection: APEX3 (Bruker, 2016); cell refinement: SAINT (Bruker, 2016); data reduction: SAINT (Bruker, 2016), CELL_NOW (Sheldrick, 2008a); program(s) used to solve structure: SHELXT (Sheldrick, 2015a); program(s) used to refine structure: SHELXL2018 (Sheldrick, 2015b); molecular graphics: DIAMOND (Brandenburg \& Putz, 2012); software used to prepare material for publication: SHELXTL (Sheldrick, 2008b).

Ethyl 2-[(2Z)-2-(2-chlorobenzylidene)-3-oxo-3,4-dihydro-2H-\1,4-benzothiazin-4-yl]acetate

Crystal data

$\mathrm{C}_{19} \mathrm{H}_{16} \mathrm{ClNO}_{3} \mathrm{~S}$

$M_{r}=373.84$

Monoclinic, $P 2_{1} / c$

$a=11.6882(2) \AA$

$b=9.0903(2) \AA$

$c=16.9533(3) \AA$

$\beta=105.105(1)^{\circ}$

$V=1739.04(6) \AA^{3}$

$Z=4$

Data collection

Bruker D8 VENTURE PHOTON 100 CMOS diffractometer

Radiation source: INCOATEC $\mathrm{I} \mu \mathrm{S}$ micro-focus source

Mirror monochromator

Detector resolution: 10.4167 pixels $\mathrm{mm}^{-1}$

$\omega$ scans

Absorption correction: multi-scan (TWINABS; Sheldrick, 2009)

Refinement

Refinement on $F^{2}$

Least-squares matrix: full

$R\left[F^{2}>2 \sigma\left(F^{2}\right)\right]=0.039$

$w R\left(F^{2}\right)=0.101$

$S=1.02$
$F(000)=776$

$D_{\mathrm{x}}=1.428 \mathrm{Mg} \mathrm{m}^{-3}$

$\mathrm{Cu} K \alpha$ radiation, $\lambda=1.54178 \AA$

Cell parameters from 9820 reflections

$\theta=3.9-74.6^{\circ}$

$\mu=3.22 \mathrm{~mm}^{-1}$

$T=150 \mathrm{~K}$

Block, colourless

$0.19 \times 0.15 \times 0.11 \mathrm{~mm}$

$T_{\min }=0.57, T_{\max }=0.72$

25761 measured reflections

25761 independent reflections

21950 reflections with $I>2 \sigma(I)$

$R_{\text {int }}=0.032$

$\theta_{\text {max }}=74.6^{\circ}, \theta_{\min }=3.9^{\circ}$

$h=-14 \rightarrow 13$

$k=-11 \rightarrow 10$

$l=-21 \rightarrow 21$

25761 reflections

292 parameters

0 restraints

Primary atom site location: dual space 
Secondary atom site location: difference Fourier map

Hydrogen site location: difference Fourier map

All $\mathrm{H}$-atom parameters refined

$w=1 /\left[\sigma^{2}\left(F_{\mathrm{o}}^{2}\right)+(0.0405 P)^{2}+0.4043 P\right]$

where $P=\left(F_{\mathrm{o}}^{2}+2 F_{\mathrm{c}}{ }^{2}\right) / 3$

$(\Delta / \sigma)_{\max }<0.001$

\author{
$\Delta \rho_{\max }=0.72$ e $\AA^{-3}$ \\ $\Delta \rho_{\min }=-0.80 \mathrm{e} \AA^{-3}$ \\ Extinction correction: SHELXL2018/1 \\ (Sheldrick, 2015b), \\ $\mathrm{Fc}^{*}=\mathrm{kFc}\left[1+0.001 \mathrm{xFc}^{2} \lambda^{3} / \sin (2 \theta)\right]^{-1 / 4}$ \\ Extinction coefficient: 0.0032 (6)
}

\section{Special details}

Experimental. Analysis of 529 reflections having $\mathrm{I} / \sigma(\mathrm{I})>12$ and chosen from the full data set with $C E L L \_N O W$ (Sheldrick, 2008a) showed the crystal to belong to the monoclinic system and to be twinned by a $180^{\circ}$ rotation about the $b$ axis. The raw data were processed using the multi- component version of SAINT under control of the two-component orientation file generated by $C E L L \_N O W$.

Geometry. All esds (except the esd in the dihedral angle between two 1.s. planes) are estimated using the full covariance matrix. The cell esds are taken into account individually in the estimation of esds in distances, angles and torsion angles; correlations between esds in cell parameters are only used when they are defined by crystal symmetry. An approximate (isotropic) treatment of cell esds is used for estimating esds involving l.s. planes.

Refinement. Refinement of $\mathrm{F}^{2}$ against ALL reflections. The weighted R-factor $\mathrm{wR}$ and goodness of fit $\mathrm{S}$ are based on $\mathrm{F}^{2}$, conventional R-factors $R$ are based on $F$, with $F$ set to zero for negative $F^{2}$. The threshold expression of $F^{2}>2 \operatorname{sigma}\left(\mathrm{F}^{2}\right)$ is used only for calculating R-factors(gt) etc. and is not relevant to the choice of reflections for refinement. R-factors based on $\mathrm{F}^{2}$ are statistically about twice as large as those based on F, and R- factors based on ALL data will be even larger.

Refined as a 2-component twin.

Fractional atomic coordinates and isotropic or equivalent isotropic displacement parameters $\left(\AA^{2}\right)$

\begin{tabular}{lllll}
\hline & $x$ & $y$ & $z$ & $U_{\text {iso }} * / U_{\text {eq }}$ \\
\hline C11 & $0.50488(5)$ & $0.51497(7)$ & $0.19568(3)$ & $0.03952(18)$ \\
S1 & $0.44083(4)$ & $0.78070(6)$ & $0.47131(3)$ & $0.02735(16)$ \\
O1 & $0.31103(13)$ & $0.39288(15)$ & $0.41536(8)$ & $0.0264(3)$ \\
O2 & $0.05392(14)$ & $0.49512(17)$ & $0.29883(9)$ & $0.0341(4)$ \\
O3 & $-0.04896(13)$ & $0.37965(16)$ & $0.37586(9)$ & $0.0306(3)$ \\
N1 & $0.21745(14)$ & $0.60019(17)$ & $0.43805(10)$ & $0.0223(3)$ \\
C1 & $0.19875(18)$ & $0.7541(2)$ & $0.42964(11)$ & $0.0216(4)$ \\
C2 & $0.08488(19)$ & $0.8137(2)$ & $0.40863(13)$ & $0.0272(4)$ \\
H2 & $0.019(2)$ & $0.750(3)$ & $0.3964(15)$ & $0.032(6)^{*}$ \\
C3 & $0.0683(2)$ & $0.9646(2)$ & $0.40245(13)$ & $0.0299(5)$ \\
H3 & $-0.010(3)$ & $1.002(3)$ & $0.3866(16)$ & $0.038(7)^{*}$ \\
C4 & $0.1643(2)$ & $1.0587(2)$ & $0.41608(13)$ & $0.0294(5)$ \\
H4 & $0.152(3)$ & $1.159(3)$ & $0.4110(17)$ & $0.045(7)^{*}$ \\
C5 & $0.2778(2)$ & $1.0009(2)$ & $0.43568(13)$ & $0.0274(4)$ \\
H5 & $0.345(2)$ & $1.066(3)$ & $0.4429(15)$ & $0.033(6)^{*}$ \\
C6 & $0.29556(17)$ & $0.8496(2)$ & $0.44327(11)$ & $0.0228(4)$ \\
C7 & $0.41573(18)$ & $0.6168(2)$ & $0.41447(11)$ & $0.0224(4)$ \\
C8 & $0.31254(18)$ & $0.5270(2)$ & $0.42214(11)$ & $0.0214(4)$ \\
C9 & $0.48358(18)$ & $0.5650(2)$ & $0.36782(12)$ & $0.0239(4)$ \\
H9 & $0.461(2)$ & $0.474(3)$ & $0.3411(15)$ & $0.030(6)^{*}$ \\
C10 & $0.58341(18)$ & $0.6384(2)$ & $0.34694(12)$ & $0.0230(4)$ \\
C11 & $0.59934(19)$ & $0.6260(2)$ & $0.26787(12)$ & $0.0266(4)$ \\
C12 & $0.6869(2)$ & $0.7022(2)$ & $0.24392(13)$ & $0.0308(5)$ \\
H12 & $0.693(2)$ & $0.689(3)$ & $0.1896(16)$ & $0.039(7)^{*}$
\end{tabular}




$\begin{array}{lllll}\text { C13 } & 0.7644(2) & 0.7914(2) & 0.29922(13) & 0.0316(5) \\ \text { H13 } & 0.826(3) & 0.842(3) & 0.2818(17) & 0.042(7)^{*} \\ \text { C14 } & 0.75389(19) & 0.8019(2) & 0.37885(13) & 0.0281(4) \\ \text { H14 } & 0.808(2) & 0.863(3) & 0.4187(16) & 0.037(7)^{*} \\ \text { C15 } & 0.66479(18) & 0.7271(2) & 0.40190(12) & 0.0255(4) \\ \text { H15 } & 0.659(2) & 0.733(2) & 0.4564(15) & 0.027(6)^{*} \\ \text { C16 } & 0.11979(18) & 0.5077(2) & 0.44607(12) & 0.0235(4) \\ \text { H16A } & 0.151(2) & 0.421(3) & 0.4763(15) & 0.029(6)^{*} \\ \text { H16B } & 0.077(2) & 0.556(3) & 0.4769(14) & 0.026(6)^{*} \\ \text { C17 } & 0.03970(18) & 0.4622(2) & 0.36420(12) & 0.0244(4) \\ \text { C18 } & -0.1348(2) & 0.3263(3) & 0.30254(15) & 0.0386(5) \\ \text { H18A } & -0.092(3) & 0.255(3) & 0.2763(18) & 0.048(8)^{*} \\ \text { H18B } & -0.161(3) & 0.410(3) & 0.2641(19) & 0.049(8)^{*} \\ \text { C19 } & -0.2350(3) & 0.2585(4) & 0.3297(2) & 0.0509(7) \\ \text { H19A } & -0.205(3) & 0.173(3) & 0.370(2) & 0.054(8)^{*} \\ \text { H19B } & -0.289(3) & 0.220(4) & 0.283(2) & 0.069(10)^{*} \\ \text { H19C } & -0.274(3) & 0.331(4) & 0.359(2) & 0.061(9)^{*} \\ \end{array}$

Atomic displacement parameters $\left(\AA^{2}\right)$

\begin{tabular}{lllllll}
\hline & $U^{11}$ & $U^{22}$ & $U^{33}$ & $U^{12}$ & $U^{13}$ & $U^{23}$ \\
\hline C11 & $0.0417(4)$ & $0.0478(3)$ & $0.0343(3)$ & $-0.0153(2)$ & $0.0194(2)$ & $-0.0140(2)$ \\
S1 & $0.0165(3)$ & $0.0318(3)$ & $0.0341(3)$ & $-0.00303(19)$ & $0.0072(2)$ & $-0.0083(2)$ \\
O1 & $0.0279(8)$ & $0.0251(7)$ & $0.0300(7)$ & $-0.0012(6)$ & $0.0143(6)$ & $0.0008(5)$ \\
O2 & $0.0335(9)$ & $0.0442(9)$ & $0.0270(7)$ & $-0.0083(7)$ & $0.0122(7)$ & $0.0003(6)$ \\
O3 & $0.0253(8)$ & $0.0361(8)$ & $0.0318(7)$ & $-0.0111(6)$ & $0.0100(6)$ & $-0.0034(6)$ \\
N1 & $0.0180(8)$ & $0.0251(8)$ & $0.0265(8)$ & $-0.0032(6)$ & $0.0104(7)$ & $0.0002(6)$ \\
C1 & $0.0196(10)$ & $0.0247(9)$ & $0.0226(8)$ & $-0.0025(8)$ & $0.0093(8)$ & $-0.0020(7)$ \\
C2 & $0.0178(10)$ & $0.0308(10)$ & $0.0340(10)$ & $-0.0033(8)$ & $0.0086(8)$ & $-0.0031(8)$ \\
C3 & $0.0215(11)$ & $0.0327(11)$ & $0.0357(11)$ & $0.0027(9)$ & $0.0080(9)$ & $-0.0027(9)$ \\
C4 & $0.0296(12)$ & $0.0246(10)$ & $0.0357(11)$ & $0.0008(9)$ & $0.0117(9)$ & $-0.0024(8)$ \\
C5 & $0.0238(11)$ & $0.0282(10)$ & $0.0323(10)$ & $-0.0061(8)$ & $0.0108(9)$ & $-0.0064(8)$ \\
C6 & $0.0170(10)$ & $0.0287(10)$ & $0.0241(9)$ & $-0.0019(8)$ & $0.0083(8)$ & $-0.0036(7)$ \\
C7 & $0.0190(10)$ & $0.0253(9)$ & $0.0236(9)$ & $-0.0012(7)$ & $0.0072(8)$ & $0.0016(7)$ \\
C8 & $0.0200(10)$ & $0.0274(10)$ & $0.0184(8)$ & $-0.0010(8)$ & $0.0076(7)$ & $0.0006(7)$ \\
C9 & $0.0217(10)$ & $0.0254(10)$ & $0.0262(9)$ & $-0.0004(8)$ & $0.0094(8)$ & $0.0020(8)$ \\
C10 & $0.0191(10)$ & $0.0252(9)$ & $0.0275(9)$ & $0.0040(7)$ & $0.0111(8)$ & $0.0039(7)$ \\
C11 & $0.0243(11)$ & $0.0282(10)$ & $0.0300(10)$ & $0.0001(8)$ & $0.0121(9)$ & $-0.0012(8)$ \\
C12 & $0.0313(12)$ & $0.0368(12)$ & $0.0298(10)$ & $-0.0013(9)$ & $0.0177(9)$ & $0.0006(9)$ \\
C13 & $0.0249(11)$ & $0.0386(12)$ & $0.0359(11)$ & $-0.0044(9)$ & $0.0164(9)$ & $0.0038(9)$ \\
C14 & $0.0181(10)$ & $0.0374(11)$ & $0.0296(10)$ & $-0.0027(9)$ & $0.0072(8)$ & $0.0006(9)$ \\
C15 & $0.0196(10)$ & $0.0333(10)$ & $0.0248(9)$ & $0.0022(8)$ & $0.0083(8)$ & $0.0038(8)$ \\
C16 & $0.0208(10)$ & $0.0267(10)$ & $0.0268(9)$ & $-0.0039(8)$ & $0.0129(8)$ & $0.0003(8)$ \\
C17 & $0.0212(10)$ & $0.0239(9)$ & $0.0307(10)$ & $-0.0017(8)$ & $0.0114(8)$ & $-0.0017(8)$ \\
C18 & $0.0306(13)$ & $0.0435(13)$ & $0.0387(12)$ & $-0.0113(11)$ & $0.0033(10)$ & $-0.0085(11)$ \\
C19 & $0.0319(15)$ & $0.0561(17)$ & $0.0614(17)$ & $-0.0187(13)$ & $0.0065(14)$ & $-0.0055(15)$ \\
& & & & & & \\
\hline
\end{tabular}


Geometric parameters $\left(\AA,{ }^{\circ}\right)$

\begin{tabular}{|c|c|c|c|}
\hline $\mathrm{C} 11-\mathrm{C} 11$ & $1.741(2)$ & $\mathrm{C} 9-\mathrm{C} 10$ & $1.465(3)$ \\
\hline $\mathrm{S} 1-\mathrm{C} 6$ & $1.755(2)$ & C9-H9 & $0.95(2)$ \\
\hline $\mathrm{S} 1-\mathrm{C} 7$ & $1.757(2)$ & $\mathrm{C} 10-\mathrm{C} 15$ & $1.401(3)$ \\
\hline $\mathrm{O} 1-\mathrm{C} 8$ & $1.224(2)$ & $\mathrm{C} 10-\mathrm{C} 11$ & $1.405(3)$ \\
\hline $\mathrm{O} 2-\mathrm{C} 17$ & $1.200(2)$ & $\mathrm{C} 11-\mathrm{C} 12$ & $1.382(3)$ \\
\hline $\mathrm{O} 3-\mathrm{C} 17$ & $1.335(2)$ & $\mathrm{C} 12-\mathrm{C} 13$ & $1.383(3)$ \\
\hline $\mathrm{O} 3-\mathrm{C} 18$ & $1.462(3)$ & $\mathrm{C} 12-\mathrm{H} 12$ & $0.95(3)$ \\
\hline $\mathrm{N} 1-\mathrm{C} 8$ & $1.381(2)$ & $\mathrm{C} 13-\mathrm{C} 14$ & $1.390(3)$ \\
\hline $\mathrm{N} 1-\mathrm{C} 1$ & $1.417(2)$ & $\mathrm{C} 13-\mathrm{H} 13$ & $0.96(3)$ \\
\hline $\mathrm{N} 1-\mathrm{C} 16$ & $1.452(2)$ & $\mathrm{C} 14-\mathrm{C} 15$ & $1.382(3)$ \\
\hline $\mathrm{C} 1-\mathrm{C} 2$ & $1.395(3)$ & C14-H14 & $0.97(3)$ \\
\hline $\mathrm{C} 1-\mathrm{C} 6$ & $1.397(3)$ & C15-H15 & $0.95(2)$ \\
\hline $\mathrm{C} 2-\mathrm{C} 3$ & $1.386(3)$ & $\mathrm{C} 16-\mathrm{C} 17$ & $1.515(3)$ \\
\hline $\mathrm{C} 2-\mathrm{H} 2$ & $0.95(3)$ & $\mathrm{C} 16-\mathrm{H} 16 \mathrm{~A}$ & $0.96(3)$ \\
\hline $\mathrm{C} 3-\mathrm{C} 4$ & $1.382(3)$ & C16-H16B & $0.92(3)$ \\
\hline $\mathrm{C} 3-\mathrm{H} 3$ & $0.94(3)$ & $\mathrm{C} 18-\mathrm{C} 19$ & $1.498(4)$ \\
\hline $\mathrm{C} 4-\mathrm{C} 5$ & $1.384(3)$ & $\mathrm{C} 18-\mathrm{H} 18 \mathrm{~A}$ & $0.99(3)$ \\
\hline $\mathrm{C} 4-\mathrm{H} 4$ & $0.93(3)$ & C18-H18B & $1.00(3)$ \\
\hline $\mathrm{C} 5-\mathrm{C} 6$ & $1.392(3)$ & C19-H19A & $1.03(3)$ \\
\hline $\mathrm{C} 5-\mathrm{H} 5$ & $0.96(3)$ & C19-H19B & $0.94(4)$ \\
\hline $\mathrm{C} 7-\mathrm{C} 9$ & $1.343(3)$ & C19-H19C & $1.00(4)$ \\
\hline $\mathrm{C} 7-\mathrm{C} 8$ & $1.490(3)$ & & \\
\hline $\mathrm{C} 11 \cdots \mathrm{C} 14^{\mathrm{i}}$ & $3.5363(9)$ & $\mathrm{O} 1 \cdots \mathrm{H} 12^{\mathrm{i}}$ & $2.560(9)$ \\
\hline $\mathrm{C} 11 \cdots \mathrm{S} 1^{\mathrm{i}}$ & $3.7268(3)$ & $\mathrm{O} 1 \cdots \mathrm{H} 15^{\mathrm{ii}}$ & $2.400(8)$ \\
\hline $\mathrm{C} 11 \cdots \mathrm{C} 10^{\mathrm{i}}$ & $3.5940(7)$ & $\mathrm{O} 2 \cdots \mathrm{H} 18 \mathrm{~B}$ & $2.545(11)$ \\
\hline $\mathrm{C} 11 \cdots \mathrm{C} 15^{\mathrm{i}}$ & $3.4359(7)$ & $\mathrm{O} 2 \cdots \mathrm{H} 13^{\mathrm{i}}$ & $2.606(10)$ \\
\hline $\mathrm{Cl1} \cdots \mathrm{H} 9$ & $2.674(8)$ & $\mathrm{O} 2 \cdots \mathrm{H} 18 \mathrm{~A}$ & $2.74(3)$ \\
\hline $\mathrm{S} 1 \cdots \mathrm{N} 1$ & $3.0100(6)$ & $\mathrm{O} 3 \cdots \mathrm{H} 16 \mathrm{~B}^{\mathrm{vi}}$ & $2.666(8)$ \\
\hline $\mathrm{S} 1 \cdots \mathrm{C} 15$ & $3.1748(8)$ & $\mathrm{C} 2 \cdots \mathrm{C} 17$ & $3.2932(10)$ \\
\hline $\mathrm{S} 1 \cdots \mathrm{O} 1^{\mathrm{ii}}$ & $3.4189(6)$ & $\mathrm{C} 4 \cdots \mathrm{C} 14^{\mathrm{iii}}$ & $3.5882(12)$ \\
\hline $\mathrm{S} 1 \cdots \mathrm{H} 15$ & $2.660(10)$ & $\mathrm{C} 2 \cdots \mathrm{H} 16 \mathrm{~B}$ & $2.621(8)$ \\
\hline $\mathrm{S} 1 \cdots \mathrm{H} 5^{\mathrm{iii}}$ & $2.906(9)$ & $\mathrm{C} 4 \cdots \mathrm{H} 14^{\mathrm{iii}}$ & $2.826(10)$ \\
\hline $\mathrm{O} 1 \cdots \mathrm{C} 17$ & $3.1263(9)$ & $\mathrm{C} 4 \cdots \mathrm{H} 12^{\mathrm{vii}}$ & $2.993(10)$ \\
\hline $\mathrm{O} 1 \cdots \mathrm{C} 12^{\mathrm{i}}$ & $3.2141(10)$ & $\mathrm{C} 5 \cdots \mathrm{H} 12^{\mathrm{vii}}$ & $2.817(10)$ \\
\hline $\mathrm{O} 1 \cdots \mathrm{C} 15^{\mathrm{ii}}$ & $3.2268(8)$ & $\mathrm{C} 7 \cdots \mathrm{H} 15$ & $2.937(9)$ \\
\hline $\mathrm{O} 2 \cdots \mathrm{N} 1$ & $2.7902(7)$ & $\mathrm{C} 15 \cdots \mathrm{H} 16 \mathrm{~A}^{\mathrm{ii}}$ & $2.900(9)$ \\
\hline $\mathrm{O} 2 \cdots \mathrm{C} 8$ & $3.2091(9)$ & $\mathrm{C} 16 \cdots \mathrm{H} 16 \mathrm{~B}^{\mathrm{vi}}$ & $2.987(9)$ \\
\hline $\mathrm{O} 2 \cdots \mathrm{C} 1$ & $3.3715(8)$ & $\mathrm{C} 16 \cdots \mathrm{H} 2$ & $2.538(9)$ \\
\hline $\mathrm{O} 2 \cdots \mathrm{C} 3^{\text {iv }}$ & $3.3498(10)$ & $\mathrm{C} 17 \cdots \mathrm{H} 2$ & $2.696(9)$ \\
\hline $\mathrm{O} 2 \cdots \mathrm{C} 2$ & $3.4103(9)$ & $\mathrm{H} 2 \cdots \mathrm{H} 16 \mathrm{~B}$ & $2.223(12)$ \\
\hline $\mathrm{O} 1 \cdots \mathrm{H} 9$ & $2.516(9)$ & $\mathrm{H} 5 \cdots \mathrm{H} 12^{\mathrm{vii}}$ & $2.444(13)$ \\
\hline $\mathrm{O} 1 \cdots \mathrm{H} 16 \mathrm{~A}$ & $2.376(9)$ & $\mathrm{H} 5 \cdots \mathrm{H} 15^{\mathrm{iii}}$ & $2.509(12)$ \\
\hline $\mathrm{O} 1 \cdots \mathrm{H} 4^{\mathrm{v}}$ & $2.806(11)$ & $\mathrm{H} 16 \mathrm{~B} \cdots \mathrm{H} 16 \mathrm{~B}^{\mathrm{vi}}$ & $2.381(13)$ \\
\hline $\mathrm{C} 6-\mathrm{S} 1-\mathrm{C} 7$ & $98.19(9)$ & $\mathrm{C} 12-\mathrm{C} 11-\mathrm{C} 11$ & $117.82(16)$ \\
\hline
\end{tabular}




\begin{tabular}{|c|c|c|c|}
\hline $\mathrm{C} 17-\mathrm{O} 3-\mathrm{C} 18$ & $116.60(16)$ & $\mathrm{C} 10-\mathrm{C} 11-\mathrm{C} 11$ & $119.98(16)$ \\
\hline $\mathrm{C} 8-\mathrm{N} 1-\mathrm{C} 1$ & $124.52(15)$ & $\mathrm{C} 11-\mathrm{C} 12-\mathrm{C} 13$ & $119.92(19)$ \\
\hline $\mathrm{C} 8-\mathrm{N} 1-\mathrm{C} 16$ & $115.56(16)$ & $\mathrm{C} 11-\mathrm{C} 12-\mathrm{H} 12$ & $118.0(16)$ \\
\hline $\mathrm{C} 1-\mathrm{N} 1-\mathrm{C} 16$ & $118.47(16)$ & $\mathrm{C} 13-\mathrm{C} 12-\mathrm{H} 12$ & $122.0(16)$ \\
\hline $\mathrm{C} 2-\mathrm{C} 1-\mathrm{C} 6$ & $118.60(18)$ & $\mathrm{C} 12-\mathrm{C} 13-\mathrm{C} 14$ & $119.4(2)$ \\
\hline $\mathrm{C} 2-\mathrm{C} 1-\mathrm{N} 1$ & $121.41(17)$ & $\mathrm{C} 12-\mathrm{C} 13-\mathrm{H} 13$ & $118.8(16)$ \\
\hline $\mathrm{C} 6-\mathrm{C} 1-\mathrm{N} 1$ & $120.00(17)$ & $\mathrm{C} 14-\mathrm{C} 13-\mathrm{H} 13$ & $121.8(16)$ \\
\hline $\mathrm{C} 3-\mathrm{C} 2-\mathrm{C} 1$ & $120.63(19)$ & $\mathrm{C} 15-\mathrm{C} 14-\mathrm{C} 13$ & $120.3(2)$ \\
\hline $\mathrm{C} 3-\mathrm{C} 2-\mathrm{H} 2$ & $120.0(15)$ & $\mathrm{C} 15-\mathrm{C} 14-\mathrm{H} 14$ & $119.2(16)$ \\
\hline $\mathrm{C} 1-\mathrm{C} 2-\mathrm{H} 2$ & $119.4(15)$ & $\mathrm{C} 13-\mathrm{C} 14-\mathrm{H} 14$ & $120.5(16)$ \\
\hline $\mathrm{C} 4-\mathrm{C} 3-\mathrm{C} 2$ & $120.6(2)$ & $\mathrm{C} 14-\mathrm{C} 15-\mathrm{C} 10$ & $121.74(18)$ \\
\hline $\mathrm{C} 4-\mathrm{C} 3-\mathrm{H} 3$ & $120.2(16)$ & $\mathrm{C} 14-\mathrm{C} 15-\mathrm{H} 15$ & $120.3(15)$ \\
\hline $\mathrm{C} 2-\mathrm{C} 3-\mathrm{H} 3$ & $119.2(16)$ & $\mathrm{C} 10-\mathrm{C} 15-\mathrm{H} 15$ & $118.0(15)$ \\
\hline $\mathrm{C} 3-\mathrm{C} 4-\mathrm{C} 5$ & $119.4(2)$ & $\mathrm{N} 1-\mathrm{C} 16-\mathrm{C} 17$ & $112.65(16)$ \\
\hline $\mathrm{C} 3-\mathrm{C} 4-\mathrm{H} 4$ & $120.0(18)$ & $\mathrm{N} 1-\mathrm{C} 16-\mathrm{H} 16 \mathrm{~A}$ & $109.1(15)$ \\
\hline $\mathrm{C} 5-\mathrm{C} 4-\mathrm{H} 4$ & $120.6(18)$ & $\mathrm{C} 17-\mathrm{C} 16-\mathrm{H} 16 \mathrm{~A}$ & $109.0(14)$ \\
\hline $\mathrm{C} 4-\mathrm{C} 5-\mathrm{C} 6$ & $120.5(2)$ & $\mathrm{N} 1-\mathrm{C} 16-\mathrm{H} 16 \mathrm{~B}$ & $109.1(15)$ \\
\hline $\mathrm{C} 4-\mathrm{C} 5-\mathrm{H} 5$ & $119.4(15)$ & $\mathrm{C} 17-\mathrm{C} 16-\mathrm{H} 16 \mathrm{~B}$ & $110.8(15)$ \\
\hline $\mathrm{C} 6-\mathrm{C} 5-\mathrm{H} 5$ & $120.1(15)$ & $\mathrm{H} 16 \mathrm{~A}-\mathrm{C} 16-\mathrm{H} 16 \mathrm{~B}$ & $106(2)$ \\
\hline $\mathrm{C} 5-\mathrm{C} 6-\mathrm{C} 1$ & $120.27(18)$ & $\mathrm{O} 2-\mathrm{C} 17-\mathrm{O} 3$ & $125.18(19)$ \\
\hline $\mathrm{C} 5-\mathrm{C} 6-\mathrm{S} 1$ & $119.21(15)$ & $\mathrm{O} 2-\mathrm{C} 17-\mathrm{C} 16$ & $125.21(18)$ \\
\hline $\mathrm{C} 1-\mathrm{C} 6-\mathrm{S} 1$ & $120.51(15)$ & $\mathrm{O} 3-\mathrm{C} 17-\mathrm{C} 16$ & $109.61(16)$ \\
\hline $\mathrm{C} 9-\mathrm{C} 7-\mathrm{C} 8$ & $118.34(17)$ & $\mathrm{O} 3-\mathrm{C} 18-\mathrm{C} 19$ & $107.0(2)$ \\
\hline $\mathrm{C} 9-\mathrm{C} 7-\mathrm{S} 1$ & $125.50(16)$ & $\mathrm{O} 3-\mathrm{C} 18-\mathrm{H} 18 \mathrm{~A}$ & $106.6(17)$ \\
\hline $\mathrm{C} 8-\mathrm{C} 7-\mathrm{S} 1$ & $116.11(14)$ & $\mathrm{C} 19-\mathrm{C} 18-\mathrm{H} 18 \mathrm{~A}$ & $113.0(17)$ \\
\hline $\mathrm{O} 1-\mathrm{C} 8-\mathrm{N} 1$ & $120.36(17)$ & $\mathrm{O} 3-\mathrm{C} 18-\mathrm{H} 18 \mathrm{~B}$ & $109.1(17)$ \\
\hline $\mathrm{O} 1-\mathrm{C} 8-\mathrm{C} 7$ & $121.99(17)$ & $\mathrm{C} 19-\mathrm{C} 18-\mathrm{H} 18 \mathrm{~B}$ & $112.6(18)$ \\
\hline $\mathrm{N} 1-\mathrm{C} 8-\mathrm{C} 7$ & $117.64(16)$ & $\mathrm{H} 18 \mathrm{~A}-\mathrm{C} 18-\mathrm{H} 18 \mathrm{~B}$ & $108(2)$ \\
\hline $\mathrm{C} 7-\mathrm{C} 9-\mathrm{C} 10$ & $127.75(19)$ & $\mathrm{C} 18-\mathrm{C} 19-\mathrm{H} 19 \mathrm{~A}$ & $111.0(18)$ \\
\hline $\mathrm{C} 7-\mathrm{C} 9-\mathrm{H} 9$ & $116.7(15)$ & $\mathrm{C} 18-\mathrm{C} 19-\mathrm{H} 19 \mathrm{~B}$ & $108(2)$ \\
\hline $\mathrm{C} 10-\mathrm{C} 9-\mathrm{H} 9$ & $115.3(15)$ & $\mathrm{H} 19 \mathrm{~A}-\mathrm{C} 19-\mathrm{H} 19 \mathrm{~B}$ & $109(3)$ \\
\hline $\mathrm{C} 15-\mathrm{C} 10-\mathrm{C} 11$ & $116.42(18)$ & $\mathrm{C} 18-\mathrm{C} 19-\mathrm{H} 19 \mathrm{C}$ & $112.1(19)$ \\
\hline $\mathrm{C} 15-\mathrm{C} 10-\mathrm{C} 9$ & $123.16(17)$ & $\mathrm{H} 19 \mathrm{~A}-\mathrm{C} 19-\mathrm{H} 19 \mathrm{C}$ & $107(2)$ \\
\hline $\mathrm{C} 11-\mathrm{C} 10-\mathrm{C} 9$ & $120.39(18)$ & $\mathrm{H} 19 \mathrm{~B}-\mathrm{C} 19-\mathrm{H} 19 \mathrm{C}$ & $111(3)$ \\
\hline $\mathrm{C} 12-\mathrm{C} 11-\mathrm{C} 10$ & $122.19(19)$ & & \\
\hline $\mathrm{C} 8-\mathrm{N} 1-\mathrm{C} 1-\mathrm{C} 2$ & $149.38(19)$ & $\mathrm{C} 9-\mathrm{C} 7-\mathrm{C} 8-\mathrm{N} 1$ & $-152.68(18)$ \\
\hline $\mathrm{C} 16-\mathrm{N} 1-\mathrm{C} 1-\mathrm{C} 2$ & $-16.2(3)$ & $\mathrm{S} 1-\mathrm{C} 7-\mathrm{C} 8-\mathrm{N} 1$ & $29.5(2)$ \\
\hline $\mathrm{C} 8-\mathrm{N} 1-\mathrm{C} 1-\mathrm{C} 6$ & $-31.3(3)$ & $\mathrm{C} 8-\mathrm{C} 7-\mathrm{C} 9-\mathrm{C} 10$ & $175.30(18)$ \\
\hline $\mathrm{C} 16-\mathrm{N} 1-\mathrm{C} 1-\mathrm{C} 6$ & $163.13(17)$ & $\mathrm{S} 1-\mathrm{C} 7-\mathrm{C} 9-\mathrm{C} 10$ & $-7.1(3)$ \\
\hline $\mathrm{C} 6-\mathrm{C} 1-\mathrm{C} 2-\mathrm{C} 3$ & $-0.8(3)$ & $\mathrm{C} 7-\mathrm{C} 9-\mathrm{C} 10-\mathrm{C} 15$ & $37.4(3)$ \\
\hline $\mathrm{N} 1-\mathrm{C} 1-\mathrm{C} 2-\mathrm{C} 3$ & $178.55(18)$ & $\mathrm{C} 7-\mathrm{C} 9-\mathrm{C} 10-\mathrm{C} 11$ & $-140.4(2)$ \\
\hline $\mathrm{C} 1-\mathrm{C} 2-\mathrm{C} 3-\mathrm{C} 4$ & $0.8(3)$ & $\mathrm{C} 15-\mathrm{C} 10-\mathrm{C} 11-\mathrm{C} 12$ & $-2.9(3)$ \\
\hline $\mathrm{C} 2-\mathrm{C} 3-\mathrm{C} 4-\mathrm{C} 5$ & $0.3(3)$ & $\mathrm{C} 9-\mathrm{C} 10-\mathrm{C} 11-\mathrm{C} 12$ & $175.1(2)$ \\
\hline $\mathrm{C} 3-\mathrm{C} 4-\mathrm{C} 5-\mathrm{C} 6$ & $-1.3(3)$ & $\mathrm{C} 15-\mathrm{C} 10-\mathrm{C} 11-\mathrm{C} 11$ & $178.57(15)$ \\
\hline $\mathrm{C} 4-\mathrm{C} 5-\mathrm{C} 6-\mathrm{C} 1$ & $1.2(3)$ & $\mathrm{C} 9-\mathrm{C} 10-\mathrm{C} 11-\mathrm{Cl}$ & $-3.5(3)$ \\
\hline $\mathrm{C} 4-\mathrm{C} 5-\mathrm{C} 6-\mathrm{S} 1$ & $-178.03(16)$ & $\mathrm{C} 10-\mathrm{C} 11-\mathrm{C} 12-\mathrm{C} 13$ & $1.7(3)$ \\
\hline $\mathrm{C} 2-\mathrm{C} 1-\mathrm{C} 6-\mathrm{C} 5$ & $-0.2(3)$ & $\mathrm{C} 11-\mathrm{C} 11-\mathrm{C} 12-\mathrm{C} 13$ & $-179.76(18)$ \\
\hline
\end{tabular}




\begin{tabular}{|c|c|c|c|}
\hline $\mathrm{N} 1-\mathrm{C} 1-\mathrm{C} 6-\mathrm{C} 5$ & $-179.53(17)$ & $\mathrm{C} 11-\mathrm{C} 12-\mathrm{C} 13-\mathrm{C} 14$ & $0.7(3)$ \\
\hline $\mathrm{C} 2-\mathrm{C} 1-\mathrm{C} 6-\mathrm{S} 1$ & $179.07(15)$ & $\mathrm{C} 12-\mathrm{C} 13-\mathrm{C} 14-\mathrm{C} 15$ & $-1.8(3)$ \\
\hline $\mathrm{N} 1-\mathrm{C} 1-\mathrm{C} 6-\mathrm{S} 1$ & $-0.3(2)$ & $\mathrm{C} 13-\mathrm{C} 14-\mathrm{C} 15-\mathrm{C} 10$ & $0.5(3)$ \\
\hline $\mathrm{C} 7-\mathrm{S} 1-\mathrm{C} 6-\mathrm{C} 5$ & $-146.23(16)$ & $\mathrm{C} 11-\mathrm{C} 10-\mathrm{C} 15-\mathrm{C} 14$ & $1.8(3)$ \\
\hline $\mathrm{C} 7-\mathrm{S} 1-\mathrm{C} 6-\mathrm{C} 1$ & $34.53(17)$ & $\mathrm{C} 9-\mathrm{C} 10-\mathrm{C} 15-\mathrm{C} 14$ & $-176.10(19)$ \\
\hline $\mathrm{C} 6-\mathrm{S} 1-\mathrm{C} 7-\mathrm{C} 9$ & $134.12(18)$ & $\mathrm{C} 8-\mathrm{N} 1-\mathrm{C} 16-\mathrm{C} 17$ & $-80.3(2)$ \\
\hline $\mathrm{C} 6-\mathrm{S} 1-\mathrm{C} 7-\mathrm{C} 8$ & $-48.28(16)$ & $\mathrm{C} 1-\mathrm{N} 1-\mathrm{C} 16-\mathrm{C} 17$ & $86.5(2)$ \\
\hline $\mathrm{C} 1-\mathrm{N} 1-\mathrm{C} 8-\mathrm{O} 1$ & $-165.71(18)$ & $\mathrm{C} 18-\mathrm{O} 3-\mathrm{C} 17-\mathrm{O} 2$ & $-0.1(3)$ \\
\hline $\mathrm{C} 16-\mathrm{N} 1-\mathrm{C} 8-\mathrm{O} 1$ & $0.3(3)$ & $\mathrm{C} 18-\mathrm{O} 3-\mathrm{C} 17-\mathrm{C} 16$ & $-179.95(18)$ \\
\hline $\mathrm{C} 1-\mathrm{N} 1-\mathrm{C} 8-\mathrm{C} 7$ & $14.8(3)$ & $\mathrm{N} 1-\mathrm{C} 16-\mathrm{C} 17-\mathrm{O} 2$ & $1.2(3)$ \\
\hline $\mathrm{C} 16-\mathrm{N} 1-\mathrm{C} 8-\mathrm{C} 7$ & $-179.20(16)$ & $\mathrm{N} 1-\mathrm{C} 16-\mathrm{C} 17-\mathrm{O} 3$ & $-179.02(16)$ \\
\hline $\mathrm{C} 9-\mathrm{C} 7-\mathrm{C} 8-\mathrm{O} 1$ & $27.9(3)$ & $\mathrm{C} 17-\mathrm{O} 3-\mathrm{C} 18-\mathrm{C} 19$ & $-171.0(2)$ \\
\hline $\mathrm{S} 1-\mathrm{C} 7-\mathrm{C} 8-\mathrm{O} 1$ & $-149.91(15)$ & & \\
\hline \multicolumn{4}{|c|}{$\begin{array}{l}\text { Symmetry codes: (i) }-x+1, y-1 / 2,-z+1 / 2 \text {; (ii) }-x+1,-y+1,-z+1 \text {; (iii) }-x+1,-y+2,-z+1 \text {; (iv) }-x, y-1 / 2,-z+1 / 2 \text {; (v) } x, y-1, z \text {; (vi) }-x,-y+1,-z+1 \text {; (vii) } \\
-x+1, y+1 / 2,-z+1 / 2 \text {. }\end{array}$} \\
\hline \multicolumn{4}{|c|}{ Hydrogen-bond geometry $\left(\AA,{ }^{o}\right)$} \\
\hline$D-\mathrm{H} \cdots A$ & $D-\mathrm{H}$ & $\mathrm{H} \cdots A$ & $D-\mathrm{H} \cdots A$ \\
\hline $\mathrm{C} 12-\mathrm{H} 12 \cdots \mathrm{O} 1^{\mathrm{vii}}$ & $0.95(3)$ & $3.214(2)$ & $126(2)$ \\
\hline $\mathrm{C} 15-\mathrm{H} 15 \cdots \mathrm{O} 1^{\mathrm{ii}}$ & $0.95(2)$ & $3.227(2)$ & $145.8(15)$ \\
\hline
\end{tabular}

Symmetry codes: (ii) $-x+1,-y+1,-z+1$; (vii) $-x+1, y+1 / 2,-z+1 / 2$. 